\title{
Reformulated Red mud: a robust catalyst for in situ catalytic pyrolysis of biomass
}

\author{
FA Agblevor ${ }^{\psi}$ H. Wang ${ }^{\psi b}$, S. Beis, K. Christian, A. Slade, O. Hietsoic, DM Santosab \\ USTAR Bioenergy Center, Biological Engineering \\ Utah State University, Logan UT 84322, USA
}

${ }^{b}$ Energy Processes \& Materials Division, Pacific Northwest National Laboratory, Richland, WA 99352, USA.

'Department of Chemistry, Middle Tennessee State University, Murfreesboro, TN 37132.

\begin{abstract}
Biomass feedstocks contain inorganic compounds generally classified as ash. The ash consists of compounds of potassium, calcium, magnesium, silicon, phosphorous and other elements. These elements have been reported to influence both the pyrolysis reactions as well as destabilizing the pyrolysis oils during storage. The inorganic elements have also been reported to deposit on catalyst surfaces during in situ catalytic pyrolysis leading to the eventual deactivation of acidic catalysts such as zeolites. The deposition of inorganic elements and their effect on formulated red mud (FRM) catalyst during in situ catalytic pyrolysis of pinyon juniper wood was investigated. The inorganic elements were measured for the fresh, coked, and regenerated catalysts. The BET specific surface area of the FRM catalyst decreased from $76 \mathrm{~m}^{2} / \mathrm{g}$ for the fresh catalyst to $53 \mathrm{~m}^{2} / \mathrm{g}$ for the stable regenerated catalyst. After three regenerations, the BET specific surface area stabilized at $53 \mathrm{~m}^{2} / \mathrm{g}$ and remained constant after all other regenerations. Potassium, calcium, magnesium, and phosphorous were deposited on the catalyst. Potassium deposition was linear with the number of regenerations while magnesium and calcium depositions were initially rapid but leveled off after three regenerations of the catalyst. Phosphorous deposition was almost linear, but the data were more scattered compared to potassium. The potassium deposition was attributed to physical phenomenon whereas calcium and magnesium depositions were more akin to chemical reactions related to the loss of BET surface area of the catalyst. The deposition of these elements on the surface of the catalyst did not deactivate it. After each catalyst regeneration, the oil yield was not significantly affected and the oil oxygen content and viscosity decreased slightly. This clearly showed that formulated red mud is a robust catalyst suitable for in situ catalytic fast pyrolysis of biomass.
\end{abstract}

Keywords: red mud, catalytic pyrolysis, pinyon juniper, alkali metal, alkaline earth metals.

$\psi$ Corresponding authors 


\section{Introduction}

Pyrolysis of biomass followed with upgrading of produced bio-oil into liquid fuels and chemicals has a potential to be a sustainable method of meeting the hydrocarbons needs of society. However, the promise of producing hydrocarbons fuels from biomass has been fraught with poor quality oils from conventional pyrolysis that do not lend themselves readily to upgrading in traditional unit operations. Properties such as, poor thermal and chemical stability, high moisture content, high acidity, high oxygen content, and low energy density, make conventional pyrolysis oils unsuitable for direct application and upgrading. ${ }^{1-10}$ Traditional upgrading methods such as solvent addition, ${ }^{11,12}$ esterification, ${ }^{13-17}$ hydrodeoxygenation, ${ }^{18-30}$ supercritical fluid treatment, ${ }^{31,32}$ aldol condensation, ${ }^{33,34}$ and co-processing with petroleum products, ${ }^{35-39}$ have all been investigated, but none of these methods have been commercialized. Current research efforts in pyrolysis oils stabilization and upgrading are focused on catalytic pyrolysis (in situ and ex situ $)^{40-52}$ followed by hydrotreating and processing in either standalone units or used as blending stock. These methods require suitable catalysts that are stable, robust, and low cost. A large number of investigations have involved various zeolite catalysts, ${ }^{40-55}$ but in general, most zeolites and other acidic catalyst tend to be deactivated by the alkali and alkaline earth metal oxides in the biomass feedstocks. ${ }^{57-59}$ The acidic catalysts also tend to be fouled by the rapid deposition of coke on the active sites. The acidic zeolites also tend to produce large fractions of aromatic compounds, which upon upgrading lowers the octane number of the fuels and therefore are only useful as blending stocks. Because of these challenges associated with the use of zeolites and other acidic catalysts new types of catalysts such as red mud, ${ }^{60-68}$ bentonite, ${ }^{69,70}$ and other oxide catalysts ${ }^{71,72}$ are being investigated for catalytic pyrolysis of biomass feedstocks to produce stable pyrolysis oils that can be easily upgraded into fuels and chemicals. The oxide catalysts have one major advantage in that they are not poisoned by the alkali and alkaline earth metals found in biomass, however, they also suffer from coke deposition on the active catalyst sites. These oxide catalysts deoxygenate the biomass through dehydration, decarbonylation, and decarboxylation, which produce large fractions of water in the subsequent pyrolysis oils.

One of the most promising oxide catalysts for biomass pyrolysis is red mud, ${ }^{60-68}$ that is a waste product from the Bayer process of converting bauxite into alumina. The major metal oxides found in red mud are $\mathrm{Fe}_{2} \mathrm{O}_{3}, \mathrm{Al}_{2} \mathrm{O}_{3}, \mathrm{TiO}_{2}, \mathrm{CaO}$, as well as minor oxides from $\mathrm{Zn}, \mathrm{V}, \mathrm{Ni}$, etc. Red mud, has been reported to be effective as HZSM-5 in the pyrolysis of biomass. ${ }^{60}$ Pyrolysis oils produced from the in situ catalytic pyrolysis of pinyon juniper were stable and could be upgraded to hydrocarbons in a single-stage hydrotreater. ${ }^{73,74}$ Other studies conducted using synthetic red mud also showed that it was an effective catalyst for biomass pyrolysis. ${ }^{64}$ Similar to other catalysts used in the in situ catalytic pyrolysis process, coke and inorganic compounds were deposited on the surface during pyrolysis. ${ }^{60}$ However, their impact on the catalytic properties of red mud catalyst is still unclear.

Apart from causing deactivation of zeolite catalysts, alkali and alkaline earth metals (AAEM), have been extensively studied for their catalytic roles in conventional biomass pyrolysis. ${ }^{83-87}$ Various 
salts of AAEM catalysts have been sorbed into biomass to investigate their influence on the pyrolysis reactions. ${ }^{83-87}$ Potassium salts have been reported to suppress levoglucosan production but favor hydroxyacetaldehyde production..$^{75-87}$ In contrast, magnesium salts favored levoglucosan production and suppressed glycoaldehyde production. ${ }^{82}$ Calcium oxides and salts tended to favor gasification of the biomass. ${ }^{80}$ Transition metals such as iron have been reported to favor levoglucosan production and Lewis acid salts such as $\mathrm{AlCl}_{3}$, and $\mathrm{ZnCl}_{2}$ also catalyze pyrolysis reactions. ${ }^{85-87}$

During in situ catalytic pyrolysis, there is a potential to deposit AAEM or their compounds on the surface of the catalysts either during the pyrolysis process or during catalysts regeneration. In the case of red mud used for in situ catalytic pyrolysis studies of biomass, the catalyst was regenerated and reused several times without any sign of catalyst deactivation. In this paper, we report the deposition of various inorganic elements and coke on the red mud catalyst surface and their effects on the catalyst activity.

\section{Materials and Methods}

Red mud samples were obtained from an alumina processing company and prepared into a suitable form for fluidization and minimizing the attrition of the catalyst as reported by Yathavan and Agblevor, ${ }^{60}$ and Agblevor et al. ${ }^{73}$ Colloidal alumina was used as binder and colloidal silica $\left(\right.$ Ludox $\left.^{\circledR}\right)$ was added to improve attrition resistance. In this process suitable proportions of red mud, colloidal alumina, and colloidal silica were mechanically mixed in a blender and then dried in an oven at $105{ }^{\circ} \mathrm{C}$ for twelve hours. The dried material was ground and sieved to particle size $180 \mu \mathrm{m}<\mathrm{d}_{\mathrm{p}}<450 \mu \mathrm{m}$. The reformulated red mud catalysts were calcined at $600{ }^{\circ} \mathrm{C}$ for six hours and sieved to particle size $180 \mu \mathrm{m}<\mathrm{d}_{\mathrm{p}}<450 \mu \mathrm{m}$ to avoid plugging of the hot gas filter used to remove biochar and fine catalyst particles. This material was used for the biomass pyrolysis. After pyrolysis, the catalysts were regenerated at $650{ }^{\circ} \mathrm{C}$ for six hours, and sieved to remove the biomass ash and make-up catalysts was added to bring it to a constant mass for each pyrolysis experiment.

The fresh (not used for pyrolysis), used, and regenerated catalysts were characterized using Brunauer-Emmette-Teller (BET) specific surface area method, as described in Jahromi and

Agblevor. ${ }^{27}$ Scanning electron microscopy (SEM) was used to analyze the surface morphology of the catalysts. Inductively coupled plasma (ICP) spectroscopy was used to determine the elemental composition of the bulk catalyst and this was complemented by $\mathrm{x}$-ray diffraction (XRD) spectroscopic analysis. The elemental composition of the catalyst surface was determined using x-ray photoelectron spectroscopy (XPS). Acid-base properties of the catalyst were determined using ammonia temperature program desorption ( $\mathrm{NH}_{3}-\mathrm{TPD}$ ) and carbon dioxide chemisorbed pulse titration ( $\left.\mathrm{CO}_{2}-\mathrm{CPT}\right)$. The SEM, XPS, $\mathrm{NH}_{3}-\mathrm{TPD}, \mathrm{CO}_{2}-\mathrm{CPT}$, pore size and pore volume were determined by the Pacific Northwest National Laboratory (PNNL), while the 
XRD analysis was conducted by the Hoffman Hazen Laboratories (Golden, CO). All other analyses were conducted in-house at Utah State University, Logan UT.

$\mathrm{N}_{2}$ adsorption/desorption isotherms at $-196^{\circ} \mathrm{C}$ were measured using a Micromeritics ASAP 2020 analyzer. The samples were out-gassed under vacuum at $150^{\circ} \mathrm{C}$. The specific surface area was calculated using the BET equation.

Elemental analysis of the samples was performed by inductively coupled plasma-optical emission spectroscopy. Solid samples were digested in aqua regia in sealed microwave vessels and then liquid was analyzed by inductively coupled plasma.

XPS measurements were performed with a Physical Electronics Quantera Scanning X-ray Microprobe using a focused monochromatic Al K $\alpha$ X-ray (1486.7 eV) source for excitation and a spherical section analyzer. The X-ray beam was incident normal to the sample and the photoelectron detector was at $45^{\circ}$ off-normal. High energy resolution spectra were collected using a pass-energy of $69.0 \mathrm{eV}$ with a step size of $0.125 \mathrm{eV}$.

Scanning electron micrographs were acquired using an FEI Helios $600 \mathrm{NanoLab}^{\mathrm{F} I B-S E M}$. $\mathrm{NH}_{3}-$ TPD was performed using a plug-flow reactor cell equipped with a TCD detector. The catalyst was treated at $150^{\circ} \mathrm{C}$ in He for 2 hours. A stream of $\mathrm{NH}_{3}(10 \%)$ in He was introduced for 1 hour at $80^{\circ} \mathrm{C}$ to saturate the catalyst surface. The sample was then purged with $\mathrm{He}$ at $100{ }^{\circ} \mathrm{C}$ in $\mathrm{He}$ for at least 3 hours to remove physisorbed $\mathrm{NH}_{3}$. $\mathrm{NH}_{3}$ desorption was then carried out by heating the sample from 373 to $773 \mathrm{~K}$ at $10 \mathrm{~K} \mathrm{~min}^{-1}$.

$\mathrm{CO}_{2}$ chemisorption was performed by pulsed titration over the catalysts treated at $150{ }^{\circ} \mathrm{C}$. Total $\mathrm{CO}_{2}$ adsorption was measured by pulsing $\mathrm{CO}_{2}$ at $40{ }^{\circ} \mathrm{C}$ in $\mathrm{He}$. Then after flowing in He for 30 min, the second adsorption was conducted by pulsing $\mathrm{CO}_{2}$ to measure physisorbed $\mathrm{CO}_{2}$. The difference was then calculated as chemisorbed $\mathrm{CO}_{2}$.

Catalytic pyrolysis was conducted in a pilot scale fluidized bed pyrolysis reactor using formulated red mud (FRM) as the catalyst bed. Ground pinyon-juniper (PJ) wood was used as the biomass feedstock. The details of the reactor description have been published previously and will not be repeated here.$^{45}$ The fluidized bed reactor was loaded with $1000 \mathrm{~g}$ of FRM catalyst and heated to reaction temperature. The catalytic pyrolysis was conducted at $450{ }^{\circ} \mathrm{C}$ using $\mathrm{N}_{2}$ as the initial fluidizing gas, which was gradually replaced with the non-condensable pyrolysis gases after compression and recycling. The moisture content of the biomass was $5 \mathrm{wt} \%$ and the biomass feed rate was $2 \mathrm{~kg} / \mathrm{h}$. The pyrolysis products were passed through a hot gas filter to separate biochar and fine catalysts from the vapors, which were then sent to two shell and tube condensers and an electrostatic precipitator (ESP) for vapor condensation. The condenser oils had high water content while the ESP oils had low water content (1-2 wt\%). During the pyrolysis, oil samples were collected on hourly basis from all the condensers and ESP. The oils from the ESP were analyzed for viscosity, density, and moisture content during the pyrolysis process. The variation in the viscosity of the ESP oil was used as indicator of catalyst activity as reported by Agblevor et al. ${ }^{73}$ Low viscosity oils implied high catalyst activity, while high viscosity oils signified 
catalyst deactivation. Most runs were conducted for five hours after which there was significant signs of catalyst deactivation as shown by the high viscosity of the ESP oil.

After each five-hour run, the catalyst and the biochar were collected from the hot gas filter and the reactor. The biochar was easily separated from the catalyst because after each run, the hematite in the FRM was converted to magnetite, which was magnetic and therefore easily separated from the biochar using a magnetic sieve. After biochar separation, the catalyst was regenerated in a muffle furnace at $650{ }^{\circ} \mathrm{C}$ overnight. The regenerated catalyst and ash from biomass were separated by sieving the mixture to remove the ash and fines from the catalyst. Any losses in catalyst due to attrition was replenished with fresh make-up catalyst. The catalyst used for these studies was regenerated for more than twenty times, without loss of activity, however, the data reported in this paper were for eight times regeneration.

At the end of each run, samples of catalyst were taken for characterization using methods described above. There were eight catalytic pyrolysis experiments using red mud as the catalyst and the corresponding regeneration of the catalyst.

The hourly oil samples collected from the ESP were analyzed for viscosity, $\mathrm{pH}$, density, Karl Fischer water content, and ultimate composition. Some of the oil samples were also hydrotreated to access their stability using a nickel on red mud ( $\mathrm{Ni} / \mathrm{RM})$ catalyst as reported in Jahromi and Agblevor. ${ }^{26-28}$

\section{Results and Discussion}

\section{Changes in FRM catalyst after single in situ catalytic fast pyrolysis (CFP).}

The red mud catalyst was prepared using a proprietary formula to reduce attrition during the fluidization processes because red mud is very soft and forms fine particles when dried. The particles under ago attrition easily and tend to block the hot gas filter. Figure 1 shows the attrition characteristics of some of the formulated red mud (FRM) catalyst. The attrition characteristics were determined by running the FRM in a glass fluidized bed reactor for 72 hours at a cold $\mathrm{N}_{2}$ flowrate of $25 \mathrm{~L} / \mathrm{min}$ and sieving samples after fluidization. The initial FRM particle size was $180 \mu \mathrm{m}<\mathrm{d}_{\mathrm{p}}<450 \mu \mathrm{m}$ and any particle size less than this range was considered as a loss and equivalent material was added as make-up. As can be seen from Figure 1, the attrition rate was strongly dependent upon the FRM formulation components. The red mud content varied from $50 \mathrm{wt} \%$ to $60 \mathrm{wt} \%$ with addition of various proportions of binders and attrition-resistant components. The attrition rate varied from $0.0267 \mathrm{~g} / \mathrm{h}$ to $0.0719 \mathrm{~g} / \mathrm{h}$. The losses ranged from $<1 \%$ to $3 \%$. Since most of the catalytic pyrolysis experiments were completed within 5 hours, it is clear that the average loss of RFM due to attrition was about $1 \%$, which is a reasonable loss and what will be acceptable on large-scale operations. The FRM with losses less than $1 \%$ was selected for the studies reported in this paper. 


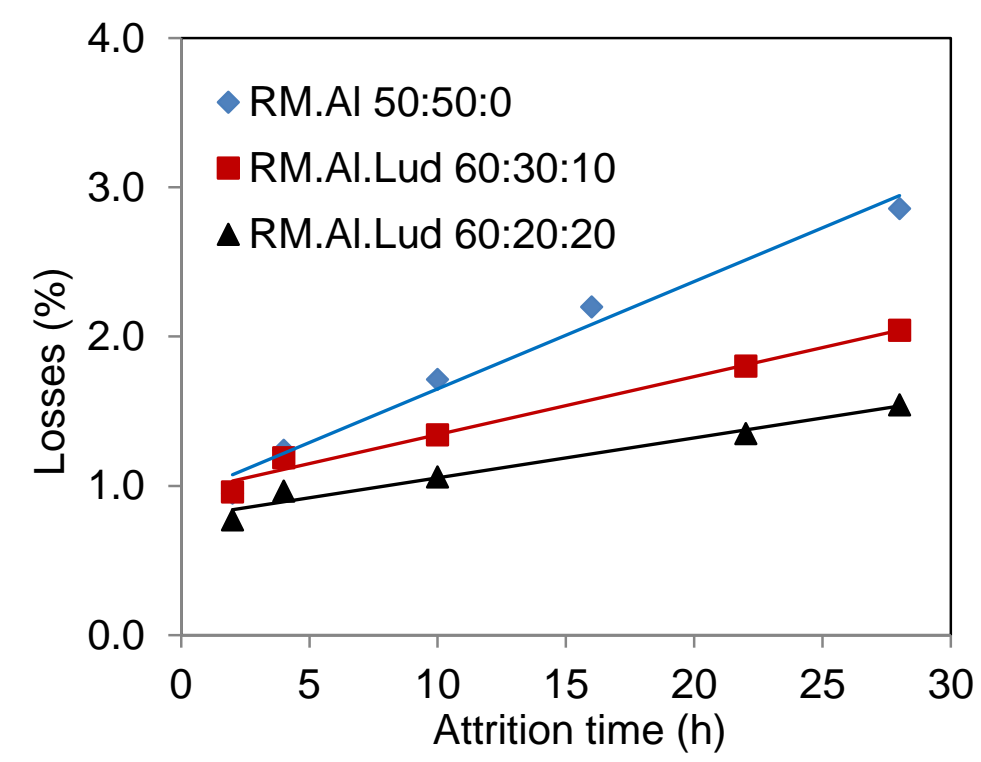

Figure 1. Attrition rate of formulated red mud catalyst with different formulation components $\left(\mathrm{RM}=\right.$ red mud; $\mathrm{Al}=$ colloidal alumina; Lud = colloidal silica $\left(\right.$ Ludox $\left.\left.^{\circledR}\right)\right)$.

The XRD analyses of the raw red mud (fresh), calcined FRM catalysts before and after pyrolysis show that the major changes occurred in each stage of the treatment. After calcination, the FRM lost some peaks that were attributed to Gibbsite $\left(\mathrm{Al}(\mathrm{OH})_{3}\right)$ and Goethite $(\mathrm{FeO}(\mathrm{OH}))$ due to dehydration of these components as reported by Agblevor et al. ${ }^{88}$ After pyrolysis, there were major changes in the structure of the catalyst due the conversion of almost all the hematite component to magnetite (see supplementary data S1). Even though there were biochar and coke on the surface of the used catalyst, there was no significant difference in the XRD spectrum of regenerated and used catalyst. These results corroborate the assertion that deactivation of the catalyst was due to fouling of the catalyst by coke which restricted access of the reactants to the active sites.

The SEM analysis of the calcined FRM and the regenerated FRM are shown in Figure 2. The surface morphology of the calcined FRM show smaller grains compared to the regenerated FRM. The regeneration appeared to increase the grain size of the catalyst probably due to sintering of some fractions during the pyrolysis and regeneration processes. The sintering of the particles is also supported by the BET specific surface analysis, which showed decrease in the specific surface area after regeneration of the catalyst. 


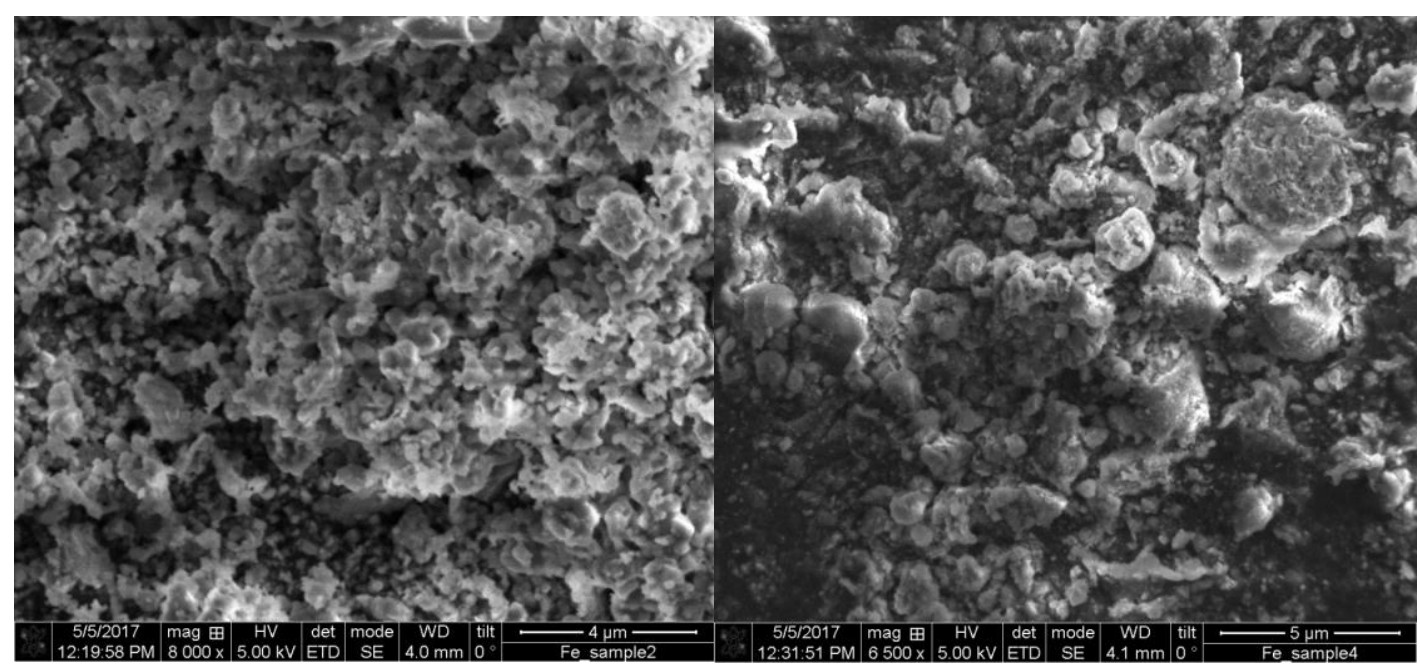

Figure 2. SEM of fresh and regenerated FRM catalysts: a) fresh catalyst; b) $1 \mathrm{X}$ regenerated catalyst.

The BET specific surface area, pore volume, and pore size of the RFM catalyst are shown in Table 1 and Figure 3. The specific surface area of FRM $\left(93.3 \mathrm{~m}^{2} / \mathrm{g}\right)$ was greater than that of the raw red mud $\left(30 \mathrm{~m}^{2} / \mathrm{g}\right)$ and regenerated FRM (Table 1$)$. The regeneration and pyrolysis processes affected the physical properties of the catalyst, which resulted in the decrease in the BET specific surface area, decrease in pore volume, and increase in the pore size. Pore size distribution (Figure 3 ) shows the loss of the smaller pores. The SEM photos (Figure 2) clearly showed increase in particle size due to particle agglomeration which could contribute to the decrease in specific surface area and decrease in the pore volume. The deposition of inorganic compounds from the biomass feedstocks also appeared to have contributed to the loss in surface area probably due to blocking of the pores as discussed below and conversion of colloidal alumina to aluminates and subsequent loss because of catalyst attrition.

\begin{tabular}{|l|l|l|l|l|l|l|l|}
\hline \multicolumn{6}{|l|}{ Table 1. Properties of fresh and regenerated FRM catalyst } \\
\hline Surface area, pore volume and pore size & \multicolumn{2}{l|}{ Acid-base properties } \\
\hline Sample & $\begin{array}{l}\text { SET }_{\text {BET }}\left(\mathrm{m}^{2} / \mathrm{g}\right) \\
\text { Polume } \\
\left(\mathrm{cm}^{3} / \mathrm{g}\right)\end{array}$ & $\begin{array}{l}\text { Pore } \\
\text { size } \\
(\mathrm{nm})\end{array}$ & $\begin{array}{l}\mathrm{NH}_{3} \text {-TPD } \\
(\mu \mathrm{mol} / \mathrm{g})\end{array}$ & $\begin{array}{l}\mathrm{NH}_{3}-\mathrm{TPD} \\
\left(\mu \mathrm{mol} / \mathrm{m}^{2}\right)\end{array}$ & $\begin{array}{l}\mathrm{CO}_{2} \text {-CPT } \\
(\mu \mathrm{mol} / \mathrm{g})\end{array}$ & $\begin{array}{l}\mathrm{CO}_{2}-\mathrm{CPT} \\
\left(\mu \mathrm{mol}_{\mathrm{m}} / \mathrm{m}^{2}\right)\end{array}$ \\
\hline $\begin{array}{l}\text { Fresh } \\
\text { catalyst }\end{array}$ & 93.3 & 0.30 & 10.8 & 95 & 1.02 & 15 & 0.16 \\
\hline $\begin{array}{l}\text { Regenerated } \\
\text { catalyst }\end{array}$ & 53.9 & 0.21 & 12.8 & 39 & 0.69 & 7 & 0.11 \\
\hline
\end{tabular}




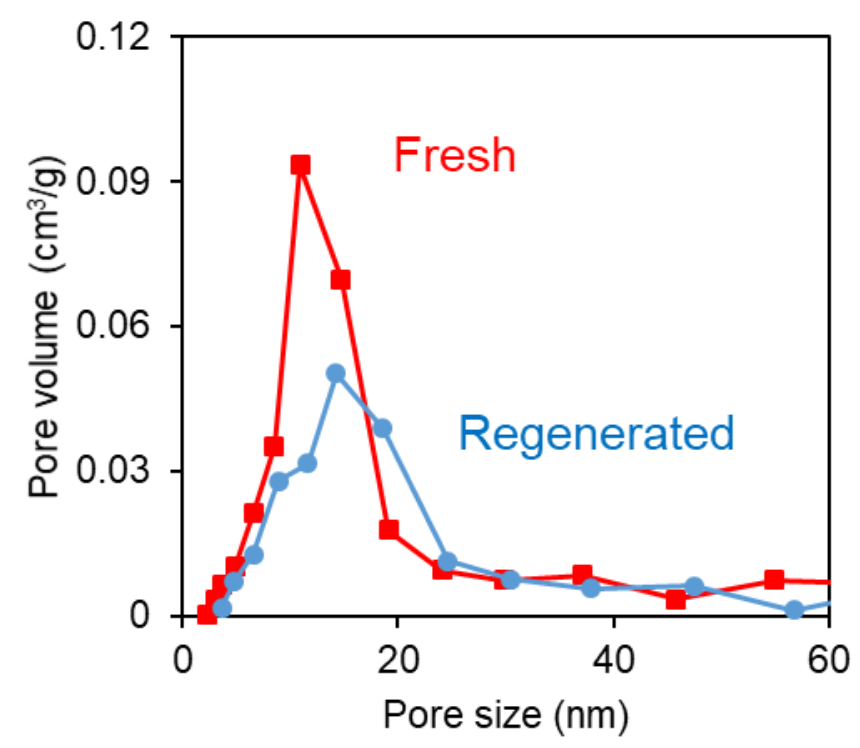

Figure 3. Pore size and volume distribution of fresh and regenerated FRM catalysts.

The acid-base properties of the FRM were determined using ammonia temperature program desorption ( $\left.\mathrm{NH}_{3}-\mathrm{TPD}\right)$ for the acidity, while carbon dioxide pulse titration $\left(\mathrm{CO}_{2}-\mathrm{PT}\right)$ was used to determine the basicity of the catalyst before and after pyrolysis. The $\mathrm{NH}_{3}$-TPD data of the fresh and regenerated catalysts are shown in Table 1 . It can be clearly seen that there were some changes in the acidity of the catalyst before and after regeneration. The specific acidity of the fresh catalyst was almost 2.4 times that of the regenerated catalyst (see Table 1), but the differences were much smaller per unit surface area basis. The decreased acidity after regeneration could be due to the deposition of the alkali and alkaline earth metals on the surface of the catalyst and also the loss of Al as shown by the decrease in the BET specific surface area.

The basicity of the fresh and regenerated catalyst show that the specific basicity of the fresh catalyst was almost twice that of the regenerated catalyst, which is similar to the trend for the acidity, but was contrary to what was expected from the deposition of basic metallic oxides. The deposition of alkali and alkaline earth metal may create basic sites if they were in oxide form, such as $\mathrm{CaO}$ or $\mathrm{MgO}$. However, it is also possible that they formed $\mathrm{CaSiO}_{3}$ or $\mathrm{MgAl}_{2} \mathrm{O}_{4}$, which are relatively neutral species. At the same time, formation of these species could also reduce existing basic sites, such as $\mathrm{TiO}_{2}$, by deposition (see supporting data $\mathrm{S} 1$ ). In general, the acid-base properties of the catalyst were retained after the regeneration.

The bulk and surface compositions of the FRM were measured using ICP and XPS respectively. The concentration of major components of the fresh and regenerated FRM are shown in Figures 4 and 5 . The variation of major elements in the bulk catalyst before and after regeneration were different for various elements. The concentrations of $\mathrm{Fe}, \mathrm{Ti}$, and $\mathrm{Na}$ were similar for both the fresh and regenerated catalysts suggesting that these components were not influenced by the 
inorganic elements in the biomass feedstock. However, $\mathrm{Al}, \mathrm{Ca}$, and $\mathrm{K}$ contents varied considerably before and after regeneration. The Al content of the FRM comprised of the alumina from the red mud and the colloidal alumina used as binder. The large decrease in the Al content of the catalyst was probably due to attrition of the binder component during fluidization and not due to leaching from the red mud. This assertion is further supported by the regeneration studies that showed the levelling of $\mathrm{Al}$ after three regenerations. It appears the original $\mathrm{Al}, \mathrm{Ti}$, and $\mathrm{Fe}$ in the red mud itself were not affected by this attrition process. The loss of Al could be due to the formation of aluminates that resulted in the loss of binding properties of the colloidal alumina and hence causing loss through attrition. In contrast, $\mathrm{Ca}$ and $\mathrm{K}$ contents increased considerably after regeneration probably because of the deposition of these elements from the biomass feedstock during the pyrolysis and regeneration of the catalyst. These increases in concentrations were also corroborated by the increases with the number of regenerations (which is equivalent to increased time on stream) as discussed below.

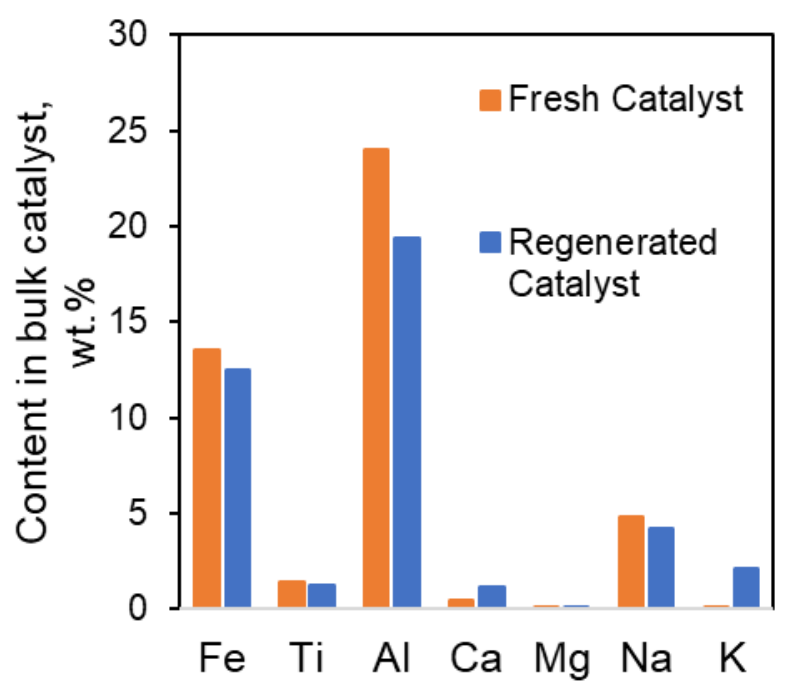

Figure 4. ICP analysis of bulk catalyst showing concentrations of major elements. 


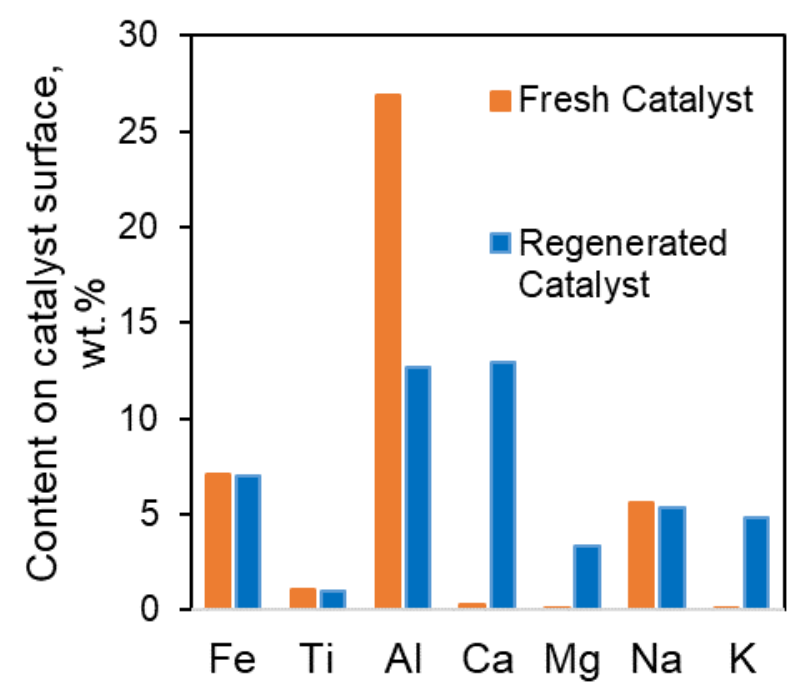

Figure 5. XPS analysis of catalyst surface showing concentrations of major elements.

The XPS analyses of the catalysts' surfaces showed a more dramatic variation of the major elements in the catalyst (Figure 5). Similar to the bulk composition, the surface $\mathrm{Fe}$, $\mathrm{Ti}$, and $\mathrm{Na}$ did not show any significant changes before and after regeneration of the catalyst (Figure 5). It appeared that these components did not undergo any sintering or agglomeration during the regeneration, and neither were there any deposition of these elements from the biomass during the pyrolysis and regeneration processes. In contrast, $\mathrm{Al}, \mathrm{Ca}, \mathrm{Mg}$, and $\mathrm{K}$ showed significant changes in the surface composition of the catalyst. In case of the $\mathrm{Al}$, there was $50 \%$ decrease in the surface composition after regeneration probably because of the formation of aluminate agglomerates and then attritive loss during the fluidized bed catalytic pyrolysis.

The $\mathrm{Ca}, \mathrm{K}$, and Mg (AAEM) had dramatic changes in the surface composition of the catalyst after pyrolysis and regeneration (pyrolysis/regeneration). In the case of $\mathrm{Ca}$, the surface composition was more than ten times that of the fresh catalyst after pyrolysis/regeneration (Figure 5). This major difference in the surface composition was attributed to deposition of $\mathrm{Ca}$ from the biomass feedstock. The analysis of the biomass ash showed that Ca content was highest at $29.5 \mathrm{wt} \%$, which explains why there was so much Ca deposition after pyrolysis/regeneration (Table 2). Further discussion of the Ca deposition is expanded in the multiple regeneration section. The $\mathrm{K}$ deposition on the surface was also very high after the pyrolysis/regeneration; but in this case, there was about five times more $K$ on the surface of the catalyst after the first pyrolysis/regeneration compared to the fresh catalyst. This high $\mathrm{K}$ on the catalyst surface was also attributed to the deposition from the biomass during the pyrolysis and regeneration processes. Similarly, the $\mathrm{Mg}$ concentration on the catalyst surface was also about five times higher than that of the fresh catalyst. The analysis of the PJ biomass ash showed high contents of all these elements, which will account for high deposition on the catalyst surface. The deposition appeared to be directly correlated with the concentration of these elements in the 
biomass. Ca concentration in the biomass ash was the highest, and therefore the surface concentration was higher than those for $\mathrm{K}$ and $\mathrm{Mg}$, which were several factors lower than the $\mathrm{Ca}$ (see Table 2). The increase in the concentration of these metals were not due enrichments through leaching of other elements because elements such as $\mathrm{Fe}, \mathrm{Ti}, \mathrm{Na}$ which do not occur in any significant quantities in the biomass did not increase in concentration on the surface or bulk of the catalyst after the regeneration.

During the pyrolysis of the PJ wood, viscosity of the ESP oil was monitored as a method of determining the activity of the catalyst. As shown in Figure 6, the viscosity of the ESP oil increased with time on stream, which was in agreement with Agblevor et al. ${ }^{73}$ This increase in viscosity with time on stream was attributed to catalyst deactivation and was corroborated by the data from the catalyst regeneration (second run). The second run was carried out after the catalyst was regenerated after 5 hours on stream when the catalyst was deemed deactivated. After regeneration, it is clear that the catalyst performance was similar to the fresh catalyst pyrolysis with respect to ESP oil viscosity variation. The data also suggested that the deactivation of the catalyst with time on stream was due to the fouling of the active sites through coke formation.

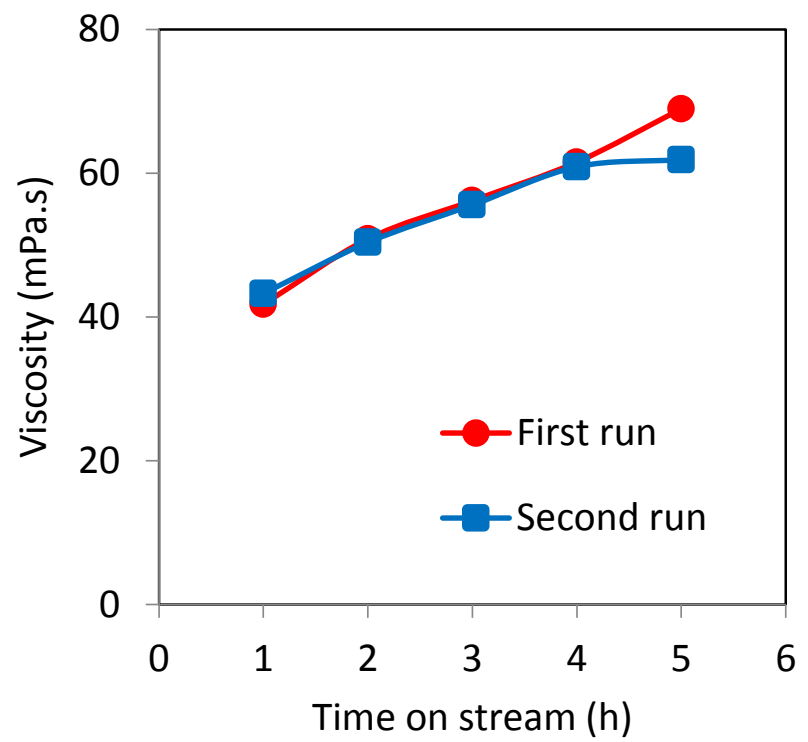

Figure 6. Comparison of catalyst activities of FRM using viscosity variation during time on stream.

In summary, although there were changes in $\mathrm{S}_{\mathrm{BET}}$, pore size, pore volume, surface and bulk compositions of the FRM catalyst, its catalytic activity during in situ CFP of biomass was fully restored after regeneration through the combustion of coke/char. The deposition of the 
inorganic elements from the biomass onto the surface of the catalyst did not deactivate or poison the catalyst.

\section{Effect of Changes in FRM catalyst after multiple in situ catalytic fast pyrolysis (CFP) and regeneration on catalyst activity and performance}

In the previous section, it was shown that biomass inorganic compounds were deposited on the catalyst after single pyrolysis and regeneration events. In this section the effect of multiple pyrolysis and regenerations events on the deposition of inorganic compounds on catalyst properties and products are discussed. The FRM catalyst was used for pyrolysis followed by regeneration for over twenty times. Several parameters were measured to ascertain the effect of multiple pyrolysis/regeneration on the physico-chemical properties of the catalyst.

The BET specific surface area $\left(\mathrm{S}_{\mathrm{BET}}\right)$ of the catalyst was measured and plotted against the number of pyrolysis/regenerations (Figure 7). It should be noted that this catalyst was prepared from another batch and therefore its initial $\mathrm{S}_{\mathrm{BET}}$ was different from the one used for the studies in the previous section. The $\mathrm{S}_{\mathrm{BET}}$ of the catalyst initially decreased during the first three pyrolysis/regenerations, and then stabilized at $53.3 \mathrm{~m}^{2} / \mathrm{g}$ without significant changes after several pyrolysis/regeneration events. The initial decreases in $\mathrm{S}_{\mathrm{BET}}$ was attributed to sintering because of chemical reaction between $\mathrm{Na}, \mathrm{Al}, \mathrm{Ca}, \mathrm{C}$, and $\mathrm{Si}$ oxides in the sample to form larger grains of sodium alumina carbonate silicate $\left(3 \mathrm{Na} \mathrm{AlSi} 4 . \mathrm{Na}_{2} . \mathrm{CO}_{3}\right)$ and attrition of colloidal alumina binder component of the catalyst.

A major contributor to the specific surface area of the catalyst was the colloidal alumina used as a binder. The alumina appeared to have reacted with some of the other catalyst components to form aluminates, which probably caused the decrease in the surface area of the catalyst as seen by the increase in grain size of the catalyst in the SEM photos (Figure 2). The decrease in SBET $_{\text {B }}$ could also be due to the deposition of various inorganic compounds from biomass on the surface and pores of the catalyst as shown by the XPS analysis of the catalyst surface discussed above. The deposits could block the pores of the catalyst and thus contribute to the reduction of the surface area over time. This contribution appeared to be limited, because although more material was deposited on the catalyst after the third regeneration, the $S_{B E T}$ remained constant probably because these later depositions occurred only on the outer surface of the catalyst and did not penetrate the pores.

\begin{tabular}{|l|l|l|l|l|l|l|l|l|l|l|}
\hline \multicolumn{1}{|c|}{ Table 2. Elemental composition of pinyon juniper biomass ash. } \\
\hline & Concentration in PJ ash (wt\%) & \multicolumn{4}{l|}{ Concentration in PJ ash (mg/kg) } \\
\hline Elements & $\mathrm{K}$ & $\mathrm{Ca}$ & $\mathrm{Mg}$ & $\mathrm{P}$ & $\mathrm{S}$ & $\mathrm{Al}$ & $\mathrm{Fe}$ & $\mathrm{Si}$ & $\mathrm{Na}$ & $\mathrm{Sr}$ \\
\hline & 1.63 & 29.50 & 1.00 & 0.51 & 0.37 & 7238 & 8792 & 14333 & 5149 & 1022 \\
\hline
\end{tabular}




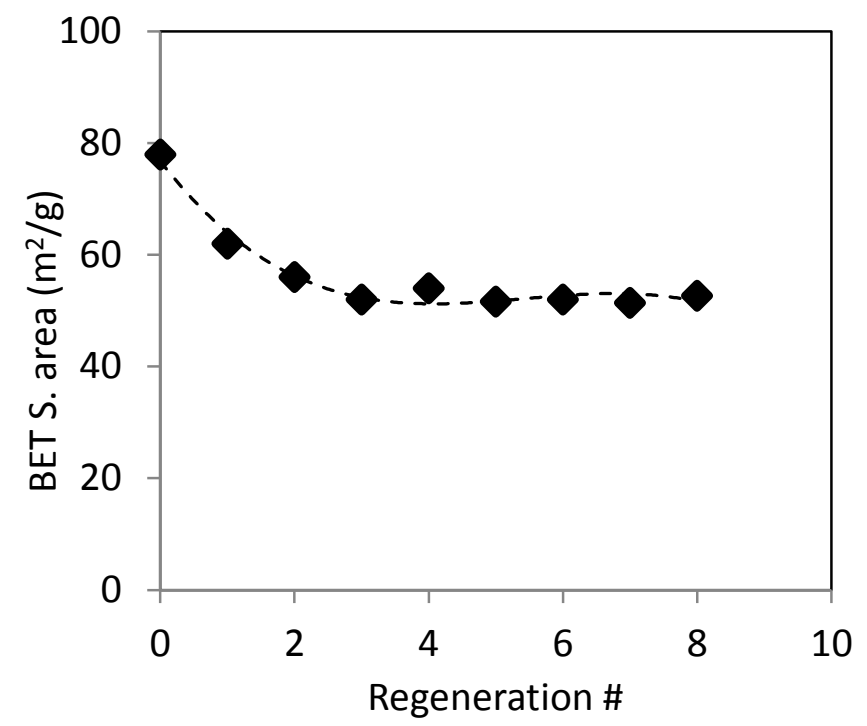

Figure 7. Variation of BET specific surface area with regeneration of the FRM catalyst.

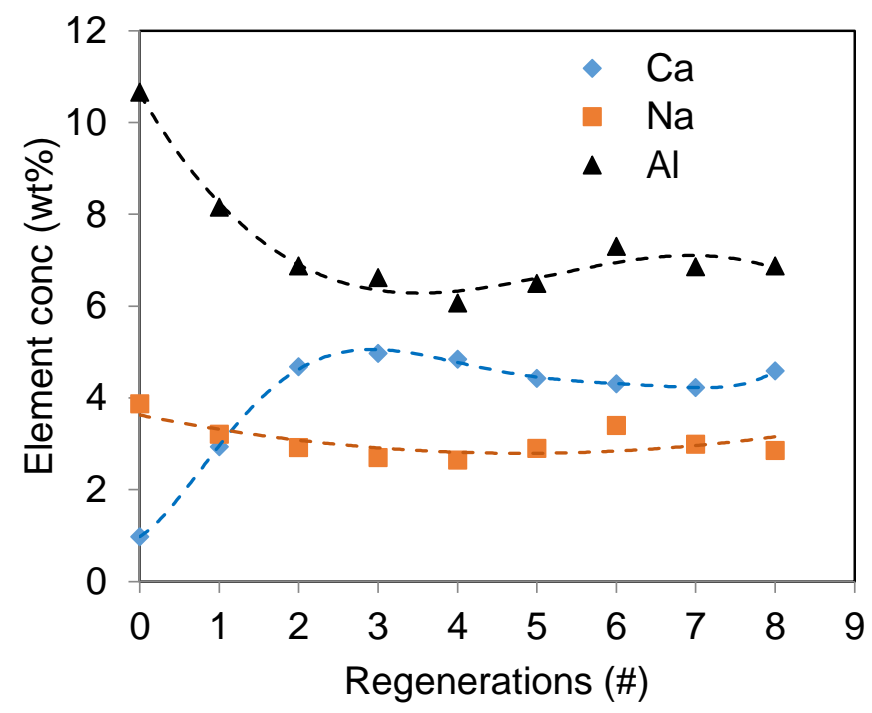

Figure 8. Variation of various elements in the bulk catalyst during regenerations.

The bulk compositional analysis of several times regenerated catalysts using ICP is shown in Figures 8 and 9. The Al content of the catalyst decreased rapidly from $10.7 \mathrm{wt} \%$ and reached a minimum of $6.0 \mathrm{wt} \%$ and then rose slightly to $7.0 \mathrm{wt} \%$ (Figure 8) probably because of the formation of aluminates and then attrition as discussed above. After each run, the catalyst was recovered by magnetic separation and then regenerated in a muffle furnace by combustion. Since only the magnetic fraction of the catalysts were collected, any attrited colloidal alumina 
and aluminates were likely to be lost and the overall alumina content of the catalyst would decrease. However, because the decreases in Al content levelled-off after the third regeneration, this suggested that only the poorly bonded colloidal alumina and aluminates were attrited from the catalyst and the core red mud catalyst with strongly bonded alumina were retained after the third regeneration.

The calcium ( $\mathrm{Ca}$ ) concentration on the catalyst increased rapidly to a maximum of $5 \mathrm{wt} \%$ and then decreased slightly to $4.3 \mathrm{wt} \%$ where it appeared to level-off. This initial rapid increase was attributed to deposition of calcium from the biomass ash component (Table 3), which reacted with the Al to form aluminates. It appeared when the alumina reactants were exhausted, the calcium reached a maximum and then decreased slightly. The slight decrease was attributed to attrition of the $\mathrm{Ca}$ that was not bonded to the alumina and was therefore lost during the magnetic separation. The increase in $\mathrm{Ca}$ content of the catalyst cannot be attributed to the relative enrichment due to the loss of alumina because $\mathrm{Na}, \mathrm{Ti}$, and $\mathrm{Fe}$, which are also components of the catalyst did not increase in concentration with the number of regenerations (Figures 4,5 and 8). This deposition of Ca can also not be necessarily detected in the XRD analysis because only crystallites can be observed in XRD analysis. Although the Ca will not vaporize easily, during the in situ biomass pyrolysis, the liquefied biomass will be in intimate contact with the catalyst and therefore inorganic elements in the liquefied biomass could be easily transferred to the catalyst. In studies reported by Stefanidis et al, ${ }^{57}$ it was observed that Ca was indiscriminatively deposited on the surface of the zeolite catalyst during in situ catalytic pyrolysis of the biomass, which also corroborates our hypothesis. In contrast, in conventional pyrolysis where there is no catalyst present, the $\mathrm{Ca}$ and other inorganic elements are retained in the biochar. Thus, to the best of our knowledge the observed increase in Ca content on the catalyst was due to deposition from the biomass, which is similar to the observations of Stefanidis et al. ${ }^{57}$

Sodium ( $\mathrm{Na}$ ) concentration in the catalyst did not appear to vary very much with the number of regenerations because $\mathrm{Na}$ content of the biomass ash was relatively low and therefore appeared to have very little deposition on the catalyst. The catalyst itself had a relatively high level of $\mathrm{Na}$ and contribution from the biomass was minimal. This observation is also in agreement with Stefanidis et $\mathrm{al}^{57}$ who also did not observe any significant changes on the deposition of $\mathrm{Na}$ from the biomass on their zeolite catalyst during in situ catalytic pyrolysis.

The potassium (K) content of the catalyst increased with each pyrolysis/regeneration event. The deposition of $\mathrm{K}$ on the catalyst increased linearly for the eight pyrolysis/regenerations (Figure 9) unlike the Ca deposition that level-off. It appeared the $\mathrm{K}$ was adsorbed on different sites that had very little interaction with the alumina and was therefore not lost by attrition. It has also been reported that the deposition of $\mathrm{K}$ on the zeolite catalyst from biomass during catalytic pyrolysis was very selective while those of $\mathrm{Ca}$ and $\mathrm{Na}$ were non-selective and mostly on the surface of the catalyst, which will corroborate our observation. Because the concentration of the potassium in both the ash and the catalyst were relatively low, the linear rate of deposition on the catalyst was not as high as the Ca deposition. $\mathrm{K}$ release from biomass has been reported to occur at low 
pyrolysis temperatures $\left(<500 \mathrm{C}\right.$ ) and at high temperatures ( $>500 \mathrm{C}$ ) during combustion. ${ }^{90-92}$ Since both pyrolysis and combustion were effected on this catalyst, it is reasonable to assume that deposits were contributed from the two processes.

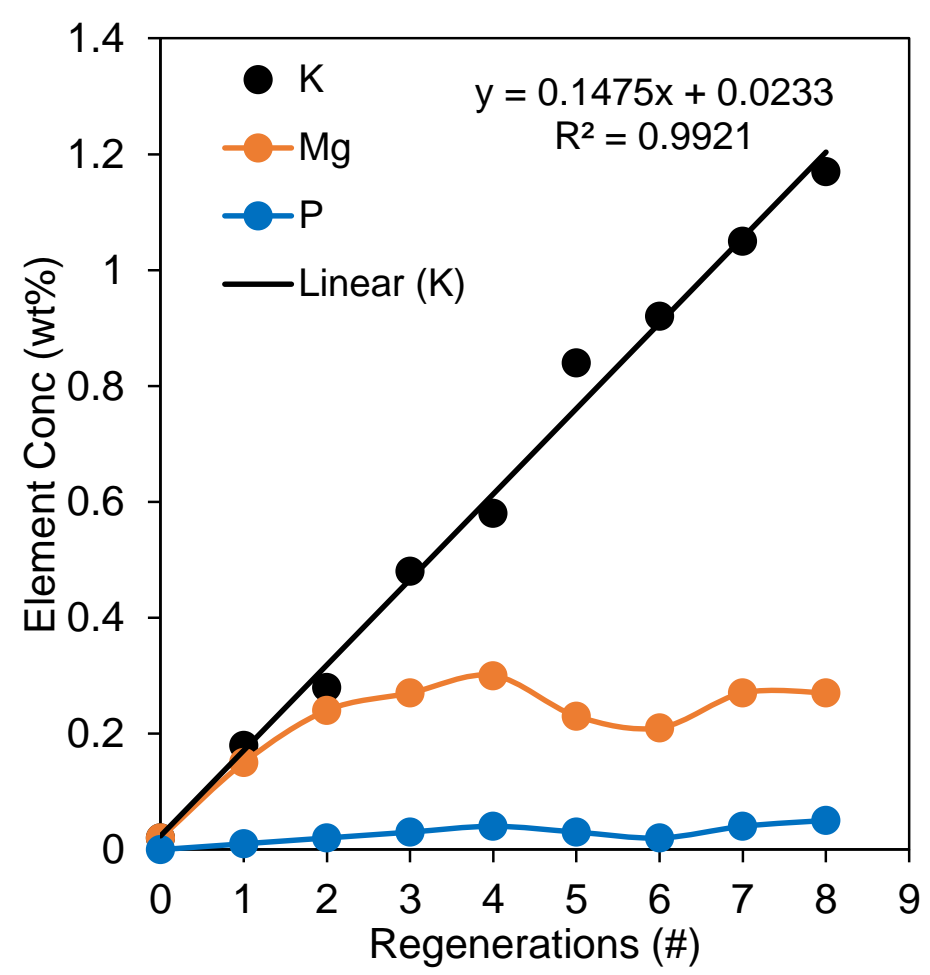

Figure 9. Variation of deposition of various elements on FRM catalyst after 8X regeneration

Magnesium (Mg) was also deposited on the catalyst after each pyrolysis/regeneration event. The trend in $\mathrm{Mg}$ deposition appeared similar to the $\mathrm{Ca}$ in that there was an initial rapid increase, which then reached a maximum then decreased slightly and then rose again. The amount of $\mathrm{Mg}$ deposited was four times less than the $K$ deposited on the catalyst although the amounts of $K$ and $\mathrm{Mg}$ in the ash were only slightly different (Table 2). It appears the rate of deposition of $\mathrm{Mg}$ was also different from that of $\mathrm{Ca}$ and this is not surprising since the release of each metal is strongly influenced by the reaction temperature and the presence of other elements such as chlorine or hydroxides.$^{90-92}$ It has been reported that the presence of chlorine in the biomass has strong influence on the release of some ash elements.$^{90-92}$ The deposition and adsorption of the $\mathrm{Mg}$ and $\mathrm{Ca}$, which are both alkaline earth metals, appeared to follow saturation kinetics, because although these elements were still present in the biomass, there were no significant increases on the catalyst surface once the surface was saturated after the third regeneration. In contrast, deposition and adsorption of $\mathrm{K}$ on the catalyst surface followed linear adsorption kinetics and 
appeared to increase infinitely. This also suggested that $\mathrm{K}, \mathrm{Mg}$, and Ca were adsorbed on different sites as also reported by other researchers. ${ }^{57}$

The phosphorous $(\mathrm{P})$ concentration in the ash was relatively low and therefore its maximum deposition was less than $0.1 \mathrm{wt} \%$. The deposition of $\mathrm{P}$ did not appear to increase with time on stream but appeared to be steady through the eight regenerations probably because of the poor volatility of $\mathrm{P}$ compounds at the pyrolysis and regeneration temperatures.

\section{Effect of inorganic elements deposition on the catalyst performance}

The effect of inorganic elements deposition on the catalyst surface was assessed by the hourly monitoring of the viscosity of the oil produced from the same PJ wood with time on stream. After the first regeneration, the performance of the catalyst (Figure 6) showed minimal loss in activity despite the deposition of inorganic compounds on the catalyst surface. The viscosity data collected for up to $14 \mathrm{X}$ pyrolysis/regenerations of the catalyst showed some interesting trends. The moisture content of the ESP oils used in these viscosity determinations ranged from 1-2\% and therefore were not significantly affected by the moisture content of the oils. We have shown in our previous publications ${ }^{28,73}$ that the ESP oils have very little moisture because most of the moisture were condensed in the two condensers before the ESP collector. A random plot of viscosity trends for the ESP oils with time on stream showed that the viscosity of the oils decreased slightly with the number of regenerations (Figure 10), which was attributed to contributions from the catalytic effect of the inorganic elements deposited on the catalyst.

The bulk compositional analysis of the used catalyst showed that the major elements deposited (Ca, K, Mg, P) levelled-off after three pyrolysis/regenerations with the exception of $\mathrm{K}$, which increased linearly. Using the linear correlation equation for $\mathrm{K}$ deposition, at the $14 \mathrm{X}$ regeneration, the $\mathrm{K}$ deposited would be $2.08 \%$. Since the deposition of the other elements levelled-off, it is therefore plausible that the change in viscosity of the ESP oils with higher regenerations was influenced by the amount of $\mathrm{K}$ deposited on the FRM. The changes in viscosity suggest that the $\mathrm{K}$ catalyzed the cracking of the higher molecular weight compounds and oligomers to lower molecular weight products, but did not produce biochar and gases in any significant quantities to influence the organic liquid yields. These results are similar to the observations of Hwang et al ${ }^{76}$ and Mourant et al ${ }^{89}$ who reported decrease in viscosity of pyrolysis oils with increase in alkali and alkaline earth metals (AAEM) content of the biomass feedstock. However, it should be noted that in the case of the above authors, the potassium was impregnated into the biomass whereas in the current study, the potassium was on the catalyst. This observation is in contrast with HZSM5 , which tends to deactivate when $\mathrm{K}$ and other alkali and alkaline earth metals were deposited on the surface and in the pores. ${ }^{57-59}$ The $\mathrm{pH}$ of the catalyst slurry did not become acidic after regeneration. In almost all cases, the $\mathrm{pH}$ of the slurry after each regeneration was 9-10.

The yields of catalytic pyrolysis products are shown in Table 3. These data showed that although there were changes in the viscosity of the oils after each regeneration, the variation in the total 
liquid yields (organic plus aqueous fractions) were minimal. The $\mathrm{pH}$ of the oils produced from each regeneration ranged 2.98-3.65 depending on the time on stream. Lower pHs were observed at the beginning of each pyrolysis, but this increased gradually with time on stream with the highest $\mathrm{pH}$ occurring after 5 hours time on stream. The density of the ESP oils also showed some slight variation (1.1 to $1.2 \mathrm{~g} / \mathrm{cm}^{3}$ ) with time on stream, but not much difference after regenerations.

\begin{tabular}{|c|c|c|c|}
\hline \multicolumn{5}{|c|}{ Table 3. Products distribution after several regenerations of FRM } \\
\hline & Total liquid & Char & Gas \\
\hline Fresh (0x) & 40.60 & 20.37 & 39.02 \\
\hline $1 X$ & 41.20 & 20.54 & 38.26 \\
\hline $2 X$ & 42.60 & 22.62 & 34.78 \\
\hline $3 X$ & 41.80 & 26.00 & 32.20 \\
\hline $6 X$ & 40.78 & 19.7 & 37.70 \\
\hline $7 X$ & 42.60 & 20.02 & 37.38 \\
\hline $8 X$ & 42.20 & 21.72 & 36.08 \\
\hline $10 X$ & 41.51 & 20.68 & 37.81 \\
\hline $14 X$ & 42.20 & 20.97 & 36.83 \\
\hline Average & $41.72 \pm 0.70$ & $21.40 \pm 1.83$ & $36.67 \pm 1.97$ \\
\hline
\end{tabular}

The $\mathrm{C}, \mathrm{H}, \mathrm{N}, \mathrm{O}, \mathrm{S}$ analyses of the ESP oils taken at steady state at the end third hour on stream is shown in Table 4. The data showed slight improvement in oxygen content of oil with regeneration of the catalyst. This reduction in oxygen content was corroborated by the data in Figure 10, which showed lower viscosity of the oils as the number of regenerations increased. The $\mathrm{K}$ deposited on the catalyst surface probably catalyzed the deoxygenation reactions similar to those reported by Imran et al.$^{72}$ Imran et al ${ }^{72}$ reported that pyrolysis of biomass mixed with alumina supported sodium carbonate $\left(\mathrm{NaCO}_{3} / \mathrm{\gamma}-\mathrm{Al}_{2} \mathrm{O}_{3}\right)$ catalyst reduced the oxygen content of biooil from $47.5 \mathrm{wt} \%$ to $16 \mathrm{wt} \%$ and there was reduction in the acidic fraction of the oil. However, when the $\mathrm{NaCO}_{3} / \gamma-\mathrm{Al}_{2} \mathrm{O}_{3}$ catalyst was regenerated by combustion, it was permanently deactivated after the second regeneration and the loss of activity was attributed to blockage of the catalyst pores. In contrast, the FRM did not deactivate even after twenty combustion regenerations. After each regeneration, the viscosity of the oils after one hour on stream showed some slight variation, and this was attributed to the effectiveness of the catalyst regeneration. When most carbon on the surface was combusted during regeneration, the oil viscosity was low and the rate of oil viscosity increase was lower than that of the fresh catalyst, suggesting that the regeneration improved the activity of the catalyst instead of causing deactivation. 


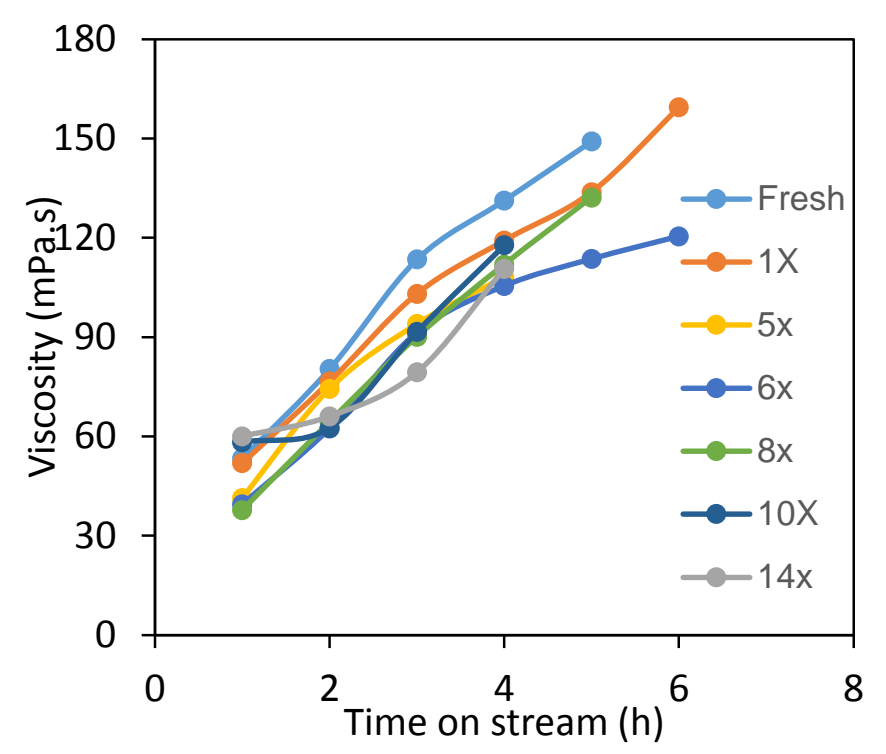

Figure 10. Variation ESP oil viscosity with time on stream and number of regenerations.

\begin{tabular}{|c|c|c|c|c|c|c|c|}
\hline \multicolumn{7}{|c|}{$\begin{array}{l}\text { Table 4. Analysis of FRM catalytic pyrolysis ESP oils taken at 3 h time on stream for } \\
\text { various catalysts }\end{array}$} \\
\hline \# Regen & $\begin{array}{c}\text { Moisture } \\
\text { (wt\%) }\end{array}$ & $\begin{array}{c}\text { Atomic } \\
\text { H/C }\end{array}$ & $\begin{array}{c}\text { Atomic } \\
\text { O/C }\end{array}$ & C (wt\%) & H (wt\%) & N (wt\%) & O*(wt\%) \\
\hline Fresh (OX) & 2.56 & 1.20 & 0.365 & 62.69 & 6.25 & 0.53 & 30.53 \\
\hline $1 X$ & 2.74 & 1.22 & 0.351 & 63.41 & 6.47 & 0.48 & 29.64 \\
\hline $2 X$ & 2.85 & 1.26 & 0.355 & 63.07 & 6.61 & 0.48 & 29.84 \\
\hline $3 X$ & 3.27 & 1.28 & 0.359 & 62.84 & 6.68 & 0.42 & 30.06 \\
\hline $4 X$ & 3.14 & 1.28 & 0.352 & 63.21 & 6.73 & 0.39 & 29.67 \\
\hline $5 X$ & 3.54 & 1.25 & 0.336 & 64.18 & 6.71 & 0.39 & 28.72 \\
\hline $6 X$ & 3.57 & 1.27 & 0.327 & 64.62 & 6.82 & 0.35 & 28.21 \\
\hline $7 X$ & 3.41 & 1.27 & 0.321 & 64.96 & 6.88 & 0.33 & 27.83 \\
\hline $8 X$ & 3.62 & 1.27 & 0.323 & 64.87 & 6.85 & 0.32 & 27.96 \\
\hline
\end{tabular}

* Oxygen determined by difference; bd = below detection

The $\mathrm{C}, \mathrm{H}, \mathrm{O}, \mathrm{N}, \mathrm{S}$ data were also analyzed with respect to the $\mathrm{H} / \mathrm{C}$ and $\mathrm{O} / \mathrm{C}$ ratios and these also showed some interesting trends. The $\mathrm{H} / \mathrm{C}$ ratios plotted against the number of regenerations (Figure 11) showed two curves. The first curve between zero and the fourth regeneration occurred during the active deposition of $\mathrm{K}, \mathrm{Mg}$, and $\mathrm{Ca}$ (AAEM) on the FRM and the second curve between the fifth and eighth regenerations occurred when the $\mathrm{Mg}$ and $\mathrm{Ca}$ depositions had plateaued and decreased while the K concentration continued to increase. In Figure 12, the slope 
of the $\mathrm{H} / \mathrm{C}$ vrs $\mathrm{Mg}$ is about 16 times higher than the $\mathrm{Ca}+\mathrm{Mg}$ slope and 18 times steeper than the AAEM slope, which suggests that $\mathrm{Mg}$ had a positive effect on $\mathrm{H} / \mathrm{C}$ ratio while $\mathrm{K}$ and $\mathrm{Ca}$ had a dilution effect on the $\mathrm{H} / \mathrm{C}$ ratio. It has been reported that $\mathrm{Mg}$ promoted the formation of levoglucosan $(\mathrm{H} / \mathrm{C}=1.7)$ and other sugar compounds while the $\mathrm{K}$ and Ca promoted decomposition of the sugars and formation of aromatic compounds which will result in a lower $\mathrm{H} / \mathrm{C}$. Compared to the fresh FRM (no regeneration), the deposition of the AAEM on the catalyst increased the $\mathrm{H} / \mathrm{C}$ ratio of the pyrolysis oil which implies improved processability of the oil.

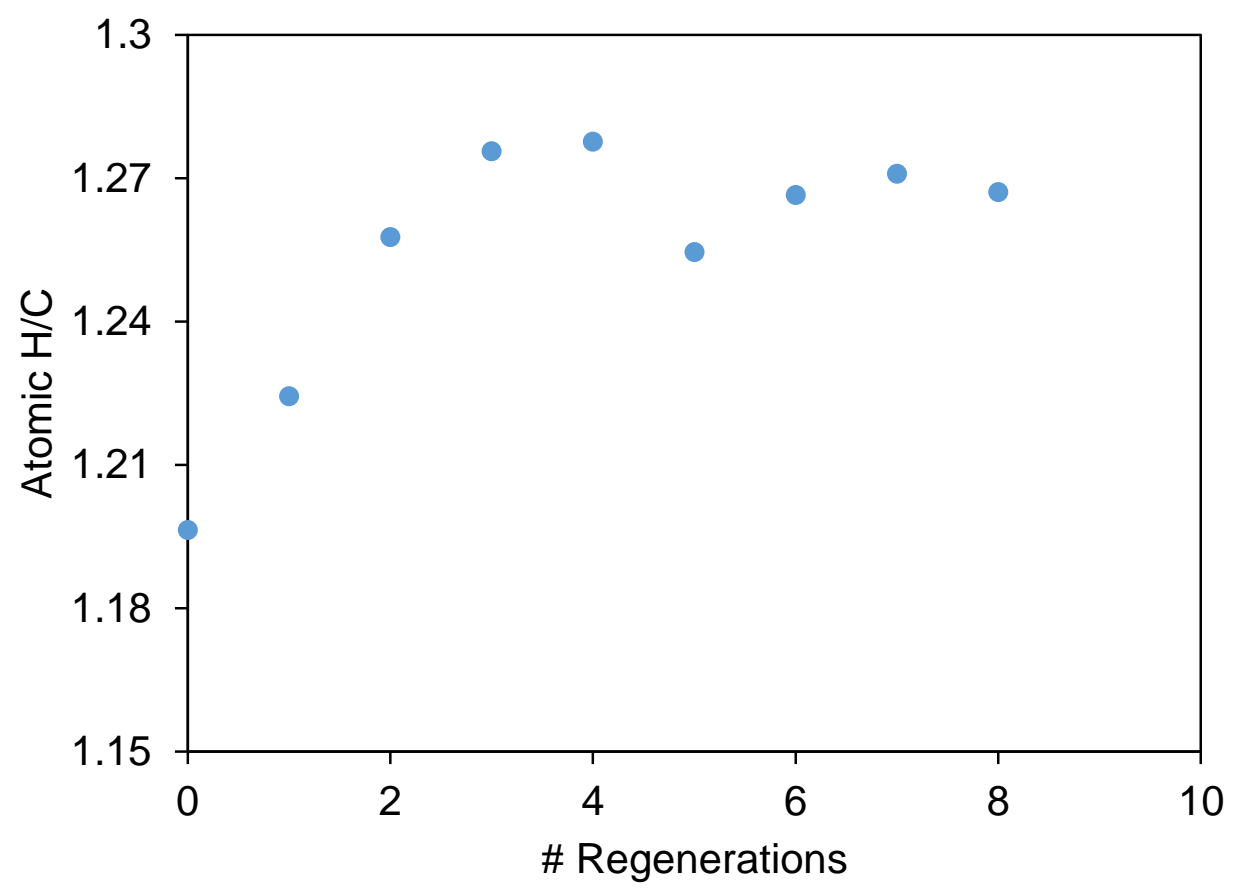

Fig 11. Effect of FRM regeneration on $\mathrm{H} / \mathrm{C}$ ratios of the catalytic pyrolysis oils $(\mathrm{H} / \mathrm{C}=$ hydrogen to carbon ratio). 


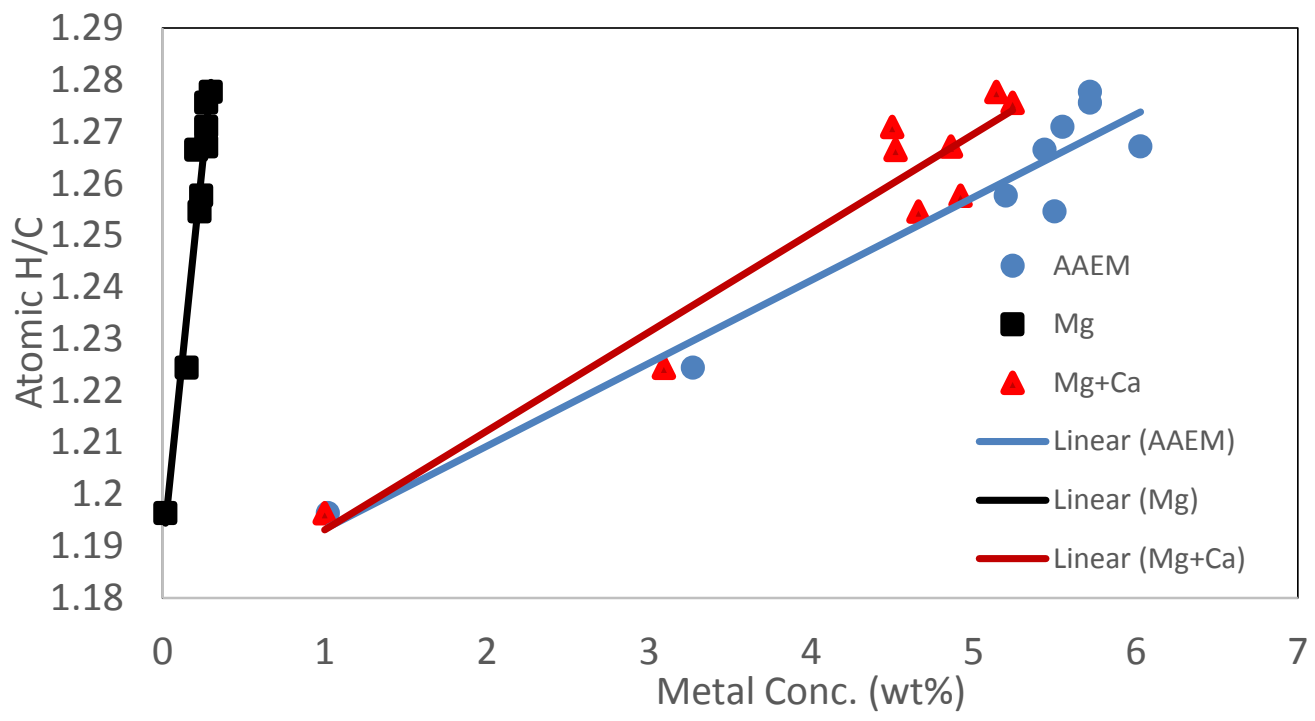

Fig 12. Effect of alkali and alkaline metal concentrations on $\mathrm{H} / \mathrm{C}$ ratios of FRM catalytic pyrolysis oils (AAEM = alkali and alkaline earth metals; $\mathrm{H} / \mathrm{C}=$ hydrogen to carbon ratio).

The $\mathrm{O} / \mathrm{C}$ ratios of the oils were also plotted against the number of regenerations (Figure 13), which showed a clear distinction between the fresh FRM and the regenerated catalysts that contained various concentrations of AAEM. This curve showed a maximum at the third regeneration when the Ca content of the catalyst was highest. The $\mathrm{O} / \mathrm{C}$ started to decrease when $\mathrm{Ca}$ and $\mathrm{Mg}$ plateaued and started to decrease while the $\mathrm{K}$ content increased. This suggested that $\mathrm{K}$ promoted the deoxygenation of the pyrolysis oils while $\mathrm{Ca}$ and $\mathrm{Mg}$ increased it. Imran et $\mathrm{al}^{72}$ also observed decrease in oxygen content of their pyrolysis oils when $\mathrm{NaCO}_{3} / \gamma-\mathrm{Al}_{2} \mathrm{O}$ was used for in situ pyrolysis of biomass, which is in agreement with the current results. Thus, there is some synergistic effect of the AAEM on the FRM catalyst activity. A plot of AAEM versus O/C (Figure 14) showed a cluster of three outliers to the general inverse correlation between the AAEM and $\mathrm{O} / \mathrm{C}$ ratio. The three outliers contained relatively high levels of $\mathrm{Ca}$ and $\mathrm{Mg}$ and low levels of $\mathrm{K}$, which again confirm the negative influence of $\mathrm{Ca}$ and $\mathrm{Mg}$ elements on the deoxygenation of the pyrolysis oils. 


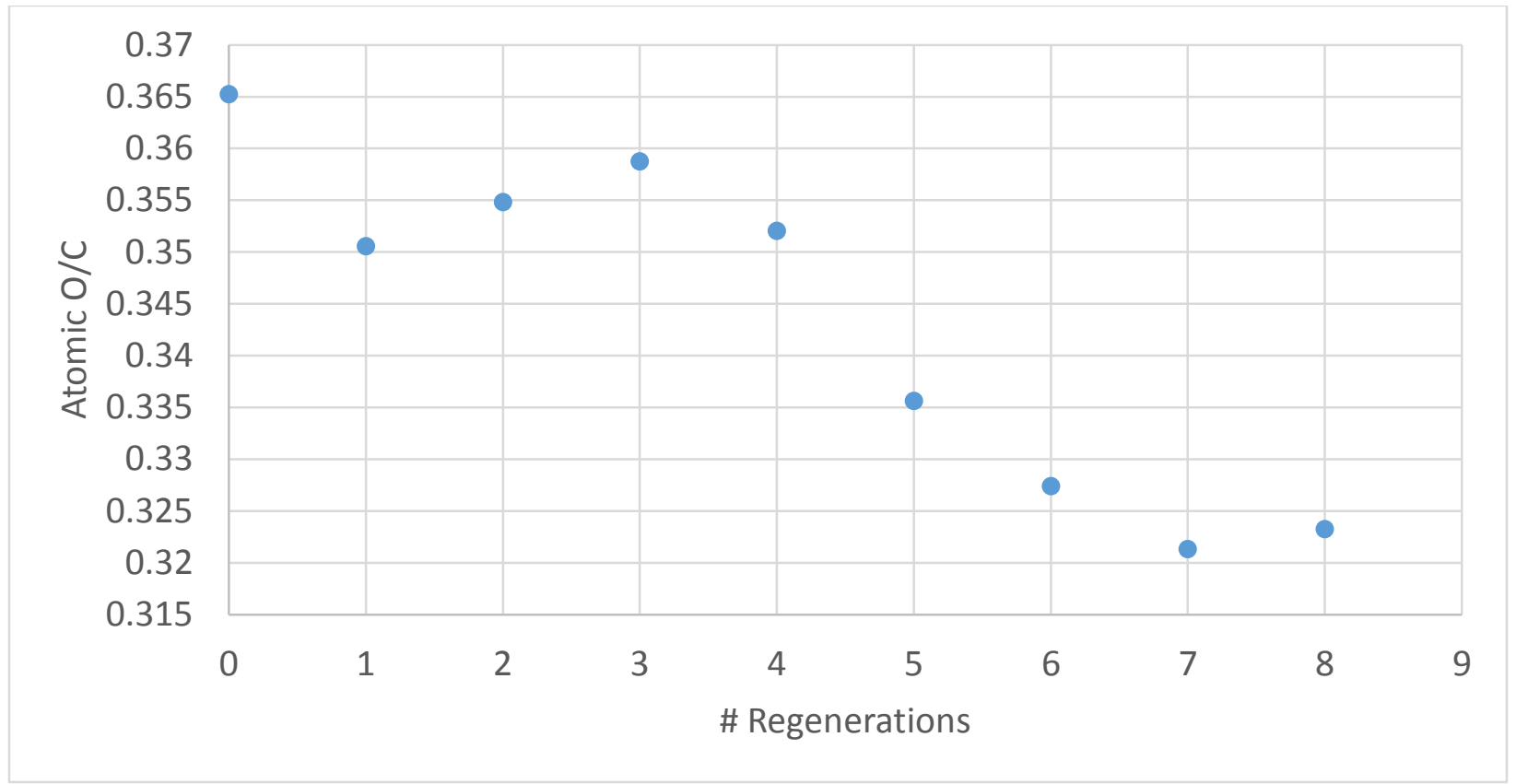

Fig 13. Effect of FRM regeneration of the $\mathrm{O} / \mathrm{C}$ ratio of in situ catalytic pyrolysis oils $(\mathrm{O} / \mathrm{C}=$ oxygen to carbon ratio). 


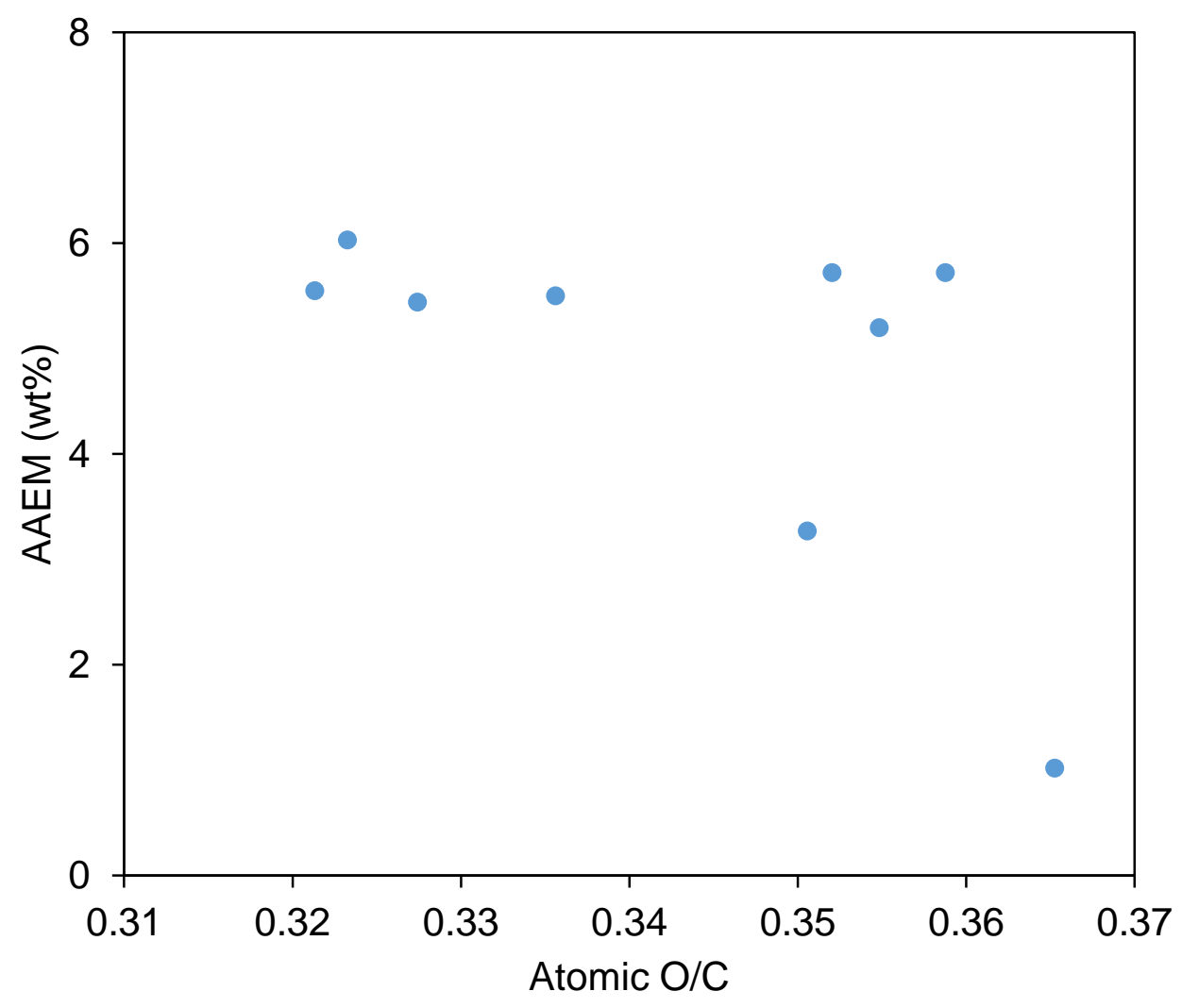

Fig 14. The effect of AAEM concentration on the O/C ratios of FRM in situ catalytic pyrolysis oils (AAEM = alkali and alkaline earth metals; $\mathrm{O} / \mathrm{C}=$ oxygen to carbon ratio). 


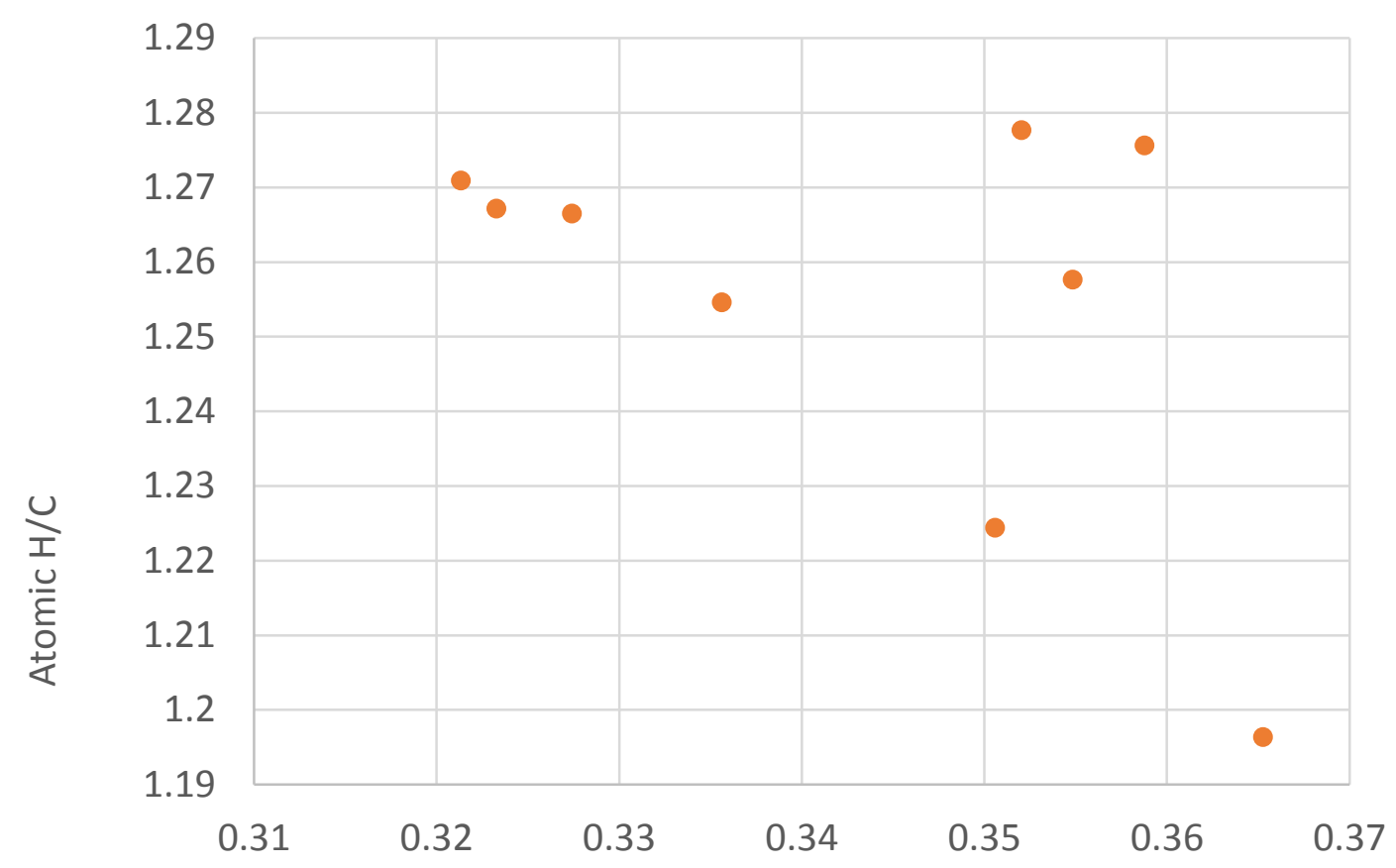

Atomic $\mathrm{O} / \mathrm{C}$ ratio

Fig 15. Van Krevelen diagram of FRM in situ catalytic pyrolysis oils ( $\mathrm{O} / \mathrm{C}=$ oxygen to carbon ratio; $\mathrm{H} / \mathrm{C}=$ hydrogen to carbon ratio).

The van Krevelen diagram (Fig 15) of the FRM oils showed very interesting trend. In general, as the $\mathrm{H} / \mathrm{C}$ ratio increased the $\mathrm{O} / \mathrm{C}$ ratio decreased showing increased energy content of the oil with decreasing $\mathrm{O} / \mathrm{C}$ ratio. However, three samples formed a cluster of outliers in this general inverse correlation between $\mathrm{H} / \mathrm{C}$ and $\mathrm{O} / \mathrm{C}$ suggesting that although they had relatively high $\mathrm{H} / \mathrm{C}$ ratios, their energy contents were relatively low. These three samples were generated with catalysts containing very high $\mathrm{Ca}$ and $\mathrm{Mg}$ contents and low $\mathrm{K}$ content in the early stages of the catalyst regeneration, when the catalyst had not attained steady state $S_{\text {BET. }}$. When the catalyst was in the steady state after three regenerations, the negative effects of the Ca and $\mathrm{Mg}$ were countered by the positive effects of $\mathrm{K}$ to produce oils with relatively high energy contents. This again shows that the deposition of the inorganic elements on this catalyst had beneficial synergistic effects on the oil properties.

The data from the catalyst characterization and product yields after multiple pyrolysis/regenerations clearly show that the FRM is regenerable, robust, and effective for in situ CFP of biomass feedstocks. 


\section{Conclusions}

It was demonstrated that reformulated red mud (FRM) is a robust suitable catalyst for in situ catalytic pyrolysis of biomass feedstocks. During pyrolysis/regenerations, there was some slight agglomeration of the catalyst, which then stabilized after three regenerations, but there was no significant loss of activity over time other than that due to fouling from coke. The loss of catalyst activity that was manifested as increase in pyrolysis oil viscosity due to fouling by coke deposition on its surface. When the catalyst was regenerated several times by combustion of the coke, the activity was fully restored each time. The pyrolysis/regeneration deposited inorganic components of biomass ( $\mathrm{Ca}, \mathrm{K}, \mathrm{Mg}$, and $\mathrm{P}$ ) on the catalyst at different rates. The $\mathrm{Ca}$ and $\mathrm{Mg}$ depositions followed saturation kinetics while the $K$ deposition was linear. Although significant quantities of the inorganic elements were deposited on the catalyst, this did not have any negative influence on the catalyst activity probably because the FRM has basic properties, which is compatible with the alkali nature of the inorganic elements of the biomass. The AAEM deposited on the catalyst also had some catalyst effect on the pyrolysis process. Unlike zeolite or other acidic catalyst that are deactivated by the inorganic elements, FRM catalyst was not deactivated by these compounds in the biomass feedstocks, but acted synergistically to improve the quality of the oil.

\section{Acknowledgements}

The authors gratefully acknowledge the United States Department of Energy (DOE), Office of Energy Efficiency and Renewable Energy, Bioenergy Technologies Office for the support of this work. The authors would like to thank researchers at Pacific Northwest National Laboratory, Teresa Lemmon, Shari X. Lee, and Mark H. Engelhard for their technical assistance. Pacific Northwest National Laboratory is operated by Battelle for DOE.

\section{Disclaimer}

The views and opinions of the authors expressed herein do not necessarily state or reflect those of the United States Government or any agency thereof. Neither the United States Government nor any agency thereof, nor any of their employees, makes any warranty, expressed or implied, or assumes any legal liability or responsibility for the accuracy, completeness, or usefulness of any information, apparatus, product, or process disclosed, or represents that its use would not infringe privately owned rights. 


\section{References}

1. Bridgwater, A.V. A review of fast pyrolysis of biomass and products upgrading. Biomass Bioenergy 2012, 38, 68-95.

2. Mohan, D.; Pittman, C.U.; Steele, P. Pyrolysis of wood/biomass for bio-oil: a critical review. Energy Fuels 2006, 20:848-489.

3. Guedes, R.E.; Luna, A.S.; Torres, A.R. Operating parameters for bio-oil production in biomass pyrolysis: a review. J. Anal. Appl. Pyrol. 2015, 129, 134-149.

4. Ingram, L.; Mohan, D.; Steele, P.; Strobel, D.; Mitchell, B.; Mohammad, J. Pyrolysis of wood and bark in an auger reactor: physical properties and chemical analysis of the produced bio-oils. Energy Fuels 2008, 22(1):614-625.

5. Hoekstra, E.; Hogendoorn, K.J.A.; Wang, X.; Westerhof, R.J.M.; Kersten, S.R.A.; van Swaaij W.P.M. Fast pyrolysis of biomass in a fluidized bed reactor: in situ filtering of the vapors. Ind. Eng. Chem. Res.2009, 48(10), 4744-4756.

6. Agblevor, F.A.; Besler, S.; Wiselogel, A.E. Fluidized bed Pyrolysis of Stored Biomass Feedstocks. Energy Fuels 1995, 9(4), 635-640.

7. Wang, S.; Dai, G.; Yang, H.; Luo, Z. Lignocellulosic biomass pyrolysis: a state-of-the-art review, Prog.Energy Combust. Sci. 2017, 62, 33-86.

8. Xiu, S.; Shabazi, A. Bio-oil production and upgrading research: a review. Renew. Sustain. Energy Reviews 2012, 16, 4406-4414.

9. Agblevor, F.A.; Rejai, B.; Wang, D.; Wiselogel, A.; Chum, H.L. Influence of Storage Conditions on the Production of Hydrocarbons from Herbaceous Biomass. Biomass Bioenergy 1994, 7, 213-222.

10. Milne, T.A.; Agblevor, F.; Davis, M.; Deutch, S.; Johnson, D. A review of the chemical composition of fast pyrolysis oils from biomass. In Developments in Thermochemical Biomass Conversion; Bridgwater, A.V.; Boocock, D.G.B., Eds.; Blackie, London, 1997, Vol.1 p.409.

11. Diebold, J.P.; Czernik, S. Additives to lower and stabilize viscosity of pyrolysis oils during storage. Energy Fuels 1997, 11, 1081-1091.

12. Oasmaa, A.; Kuoppala, E.; Selin, J.F.; Gust, S.; Solantausta, Y. Fast pyrolysis of forestry residue and pine. 4. Improvement of the product quality by solvent addition. Energy Fuels 2004, 18(5), 1578-1583.

13. Ghodke, P.; Krishna, S.V. Effect of Heterogeneous Catalyst on Esterification of Pyrolysis Oil. In: Nanotechnology for Energy and Water; Anand, G.; Pandey, J.; Rana, S. Eds Springer Proceed. Energy. Springer, Cham. ICNEW 2017. DOI https://doi.org/10.1007/978-3-319-63085-4 30.

14. Prasertpong, P.; Tippayawong, N. Upgrading pyrolysis oil model compound via esterification: Kinetic study using heteropoly acid. Energy Procedia, 2019, 160, 253259.

15. Sundqvist, T.; Oasmaa, A.; Koskinen, A. Upgrading fast pyrolysis bio-oil quality by esterification and azeotropic water removal. Energy Fuel 2015, 29, 2527-2534. 
16. Wu, L.; Hu, X.; Wang, S.; Mourant, D.; Song, Y.; Li, T. Formation of coke during the esterification of pyrolysis bio-oil. RSC Advances 2016, 6, 86485-86493.

17. Xiong, W.M.; Zhu, M.; Deng, L.; Fu, Y.; Guo, Q.X. Esterification of organic acid in biooil using acidic ionic liquid catalysts. Energy Fuels 2009, 23, 2278-2283.

18. Zacher, A.H.; Olarte, M.V.; Santosa, D.M.; Elliott, D.C.; Jones, S.B. A review and perspective of recent bio-oil hydrotreating research. Green Chemistry 2014, 16, 491515.

19. Elliott, D.C.; Hart, T.R.; Neuenschwander, G.G.; Rotness, L.J.; Olarte, M.V.; Solantausta, Y. Temperature-staged hydrotreating of fast pyrolysis bio-oils using a C-supported catalyst. Energy Fuels 2012, 26, 3891-3896.

20. Elliott, D.C.; Neuenschwander, G.G.; Hart, T.R. Hydrotreating phase-separated bio-oil with product fractions recovery. ACS Sustain. Chem. Eng. 2013, 1(4), 389-392.

21. Elliott, D.C.; Wang, H.; French, R.; Deutch, S.; Ilsa, K. Hydrocarbon liquid production from biomass via hot-vapor filtered fast pyrolysis and catalytic hydroprocessing of the bio-oil. Energy Fuels 2014, 28, 5009-5917.

22. Schwaiger, N.; Siebenhofter, M.; Elliott, D.C.; Wang, H.; Ritzberger, J.; Pucher, P. Hydrocarbon liquid production via biorack process and catalytic hydroprocessing of the product oil. Green Chemistry 2015, 17, 2487-2494.

23. Wildschut, J.; Mahfud, F.H.; Venderbosch, R.H.; Heeres, H.J. Hydrotreatment of fast pyrolysis oil using heterogeneous noble-metal catalysts. Ind. Eng. Chem. Res. 2009, 48, 10324-10334.

24. Elliott, D.C.; Hart, T.R.; Neuenschwander, G.G.; Rotness, L.J.; Zacher, A.H. Catalytic hydroprocessing of biomass fast pyrolysis bio-oil to produce hydrocarbon products. Environ. Prog. Sustain. Energy 2009, 28, 441-449

25. Gholizadeh, M.; Gunawan, R.; Hu, X.; de Miguel Mercader, F.; Westerhof, R.; Chaitwat, W.; Hasan, M.M.; Mourant, D.; Li, C.-Z. Effects of temperature on the hydrotreatment behavior of pyrolysis bio-oil and coke formation in a continuous hydrotreatment reactor. Fuel Process. Technol. 2016, 148, 175-183]

26. Jahromi, H.; Agblevor, F.A. Hydrodeoxygenation of aqueous-phase pyrolysis oil to liquid hydrocarbons using multifunctional nickel catalyst. Ind. Eng. Chem. Res. 2018, 57, 13257-13258.

27. Jahromi, H.; Agblevor, F.A. Hydrotreating of guaiacol: a comparative study of red mud supported nickel and commercial Ni/SiO $2-\mathrm{Al}_{2} \mathrm{O}_{3}$ catalysts. Appl. Catal. A, General 2018, 558, 109-121.

28. Jahromi, H.; Agblevor, F.A. Hydrodeoxygenation of pinyon juniper catalytic pyrolysis oil using red mud supported nickel catalyst. Appl. Catal. B: Environmental 2018, 236, 1-12.

29. Wang, H.; Male, J.; Wang, Y. Recent advances in hydrotreating pyrolysis bio-oil and its oxygen-containing model compounds. ACS Catal. 2013, 3, 1047-1070.

30. Jones, S.B.; Holladay, J.E.; Valkenburg, C.; Steven, D.J.; Walton, C.W.; Kinchi, C.; Elliott, D.C.; Czernik, S. Production of gasoline and diesel from biomass via fast pyrolysis, 
hydrotreating and hydrocracking: A design case, Pacific Northwest Natl. Lab.Rep, Richland, WA (USA), 2009, PNNL-18284, http://www.ntis.gov/ordering.htm.

31. Xu, X.; Zhang, C.; Zhai, Y.; Liu, Y.; Zhang, R. Upgrading bio-oil using supercritical 1butanol over a Ru/C heterogeneous catalyst: role of the solvent. Energy Fuels 2014, 28, 4611-4621.

32. Peng, J.; Chen, P.; Lou, H.; Zheng, X. Upgrading of bio-oil over aluminum silicate in supercritical ethanol. Energy Fuel 2008, 22, 3489-3492.

33. Barrett, C.J.; Chheda, J.N.; Huber, G.W.; Dumesic, J.A. Single-reactor process for sequential adol-condensation and hydrogenation of biomass-derived compounds in water. Appl. Catal. B. Environmental, 2006, 66, 111-118.

34. Faba, L.; Diaz, E.; Ordonez, S. Aqueous phase furfural-acetone aldol condensation over basic mixed oxides. Appl. Catal. B: Environmental 2012, 113-114, 201-211.

35. Agblevor, FA, Mante DO., McClung, R., Oyama, S.T. Co-processing of standard gas oil and biocrude oil to hydrocarbon fuel. Biomass Bioenergy 2012, 45, 130-137.

36. Mercader, F.deM.; Groeneveld, M.J.; Kersten, S.R.A.; Way, N.W.J. Production of advanced biofuels: co-processing of upgraded pyrolysis oils in standard refinery units. Appl. Catal. B: Environmental 2010, 96, 57-66.

37. Lindfors, C.; Paasikaillio, V.; Kuoppala, E.; Reinikainen, M.; Oasmaa, A. Co-processing of dry bio-oil, catalytic pyrolysis oil, and hydrotreated bio-oil in a microactivity test unit. Energy Fuels 2015, 29, 3707-3714.

38. Pinho, A.R.; de Almeida, M.B.B.; Mendes, F.L.; Ximenes, V.L.; Casavechia, L.C. Coprocessing raw bio-oil and gasoil in an FCC unit. Fuel Process. Technol. 2015, 131, 159 166.

39. Lappas, A.A.; Bezegianni, S.; Vasalos, L.A. Production of biofuels via co-processing in conventional refining processes. Catal. Today 2009, 145, 55-62.

40. Agblevor, F.; Mante, O.; Abdoulmoumine, N.; McClung, R. Production of stable pyrolysis oils using fractional catalytic pyrolysis, Energy Fuels 2010, 24, 4087-4089.

41. Agblevor, F.; Beis, S.; Mante, O.; Abdoulmoumine, N. Fractional catalytic pyrolysis of hybrid poplar wood. Ind. Eng. Chem. Res. 2010, 49: 3533-3538.

42. Wan, S.; Wang, Y. A review on ex-situ catalytic fast pyrolysis of biomass. Frontiers Chem. Sci. Eng. 2014, 8(3), 280-294.

43. lisa, K.; French, R.J.; Orton, K.A.; Yung, M.M.; Johnson, D.K.; Dam, J.T.; Watson, M.J.; Nimlos, M.R. In situ and ex situ catalytic pyrolysis of pine in a bench scale fluidized bed reactor system. Energy Fuels 2016, 30, 2144-2157.

44. Ruddy, D.A.; Schaidle, J.A.; Ferrell II, J.R.; Wang, J.; Moens, L.; Hensley, J.E. Recent advances in heterogeneous catalysts for bio-oil upgrading via ex-situ catalytic fast pyrolysis: catalyst development through the study of model compounds. Green Chemistry 2014, 16, 454-490. 
45. Mante, O.D., Agblevor, F.A. Catalytic pyrolysis for the production of refinery ready biocrude oils from six different biomass sources. Green Chemistry 2014, 16, 3364.3377.

46. Galadima, A.; Muraza, O. In situ fast pyrolysis of biomass with zeolite catalysts for bioaromatics/gasoline production: A review. Energy Conversion Management, 2015, 105, 338-354

47. Zhang, H.; Xiao, R.; Jin, B.; Xiao, G.; Chen, R. Biomass catalytic pyrolysis to produce olefins and aromatics with a physically mixed catalyst. Biores. Technol. 2013, 140, 256262

48. Zhang, H.; Xiao, R.; Jin, B.; Shen, D.; Chen, R.; Xiao, G. Catalytic fast pyrolysis of straw biomass in an internally interconnected fluidized bed to produce aromatics and olefins: Effect of different catalysts. Biores. Technol. 2013, 137, 82-87.

49. Hu, C., Xiao, R., Zhang, H. Ex-situ catalytic fast pyrolysis of biomass over HZSM-5 in a two-stage fluidized-bed/fixed-bed combination reactor. Biores. Technol. 2017, 243,1133-1140.

50. Andrade, L.A.; Batista, F.R.X.; Lira, T.S.; Barrozo, M.A.S.; Vieira, L.G.M. Characterization and product formation during the catalytic and non-catalytic pyrolysis of the green microalgae chlamydomonas reinhardtii. Renew. Energy, 2018, $19,731-740$.

51. Lu, Q.; Zhou, M., Li, W.; Wang, X.; Cui, M.; Yang, Y. Catalytic fast pyrolysis of biomass with noble metal-like catalysts to produce high-grade bio-oil: Analytical py-gc/ms study. Catal. Today, 2018, 302,169-179.

52. Ro, D.; Kim, Y-M.; Lee I-G.; Jae, J.; Jung, S-C.; Kim , S.C., Park, Y-K. Bench scale catalytic fast pyrolysis of empty fruit bunches over low cost catalysts and HZSM-5 using a fixed bed reactor. J. Cleaner Production 2018, 176, 298-303.

53. Marker, T.; Felix, L.; Linck, M. Integrated hydropyrolysis and hydroconversion process for production of gasoline and diesel fuel from Biomass. AICHE Extended Abstract, 2009.

54. Balagurumurthy, B.; Bhaskar, T. Hydropyrolysis of lignocellulosic biomass: a state-ofthe art review. Biomass Convention Biorefinery 2014, 4, 67-75.

55. Dayton, D.C.; Hlebak, J.; Carpenter, J.H.; Wang, K.; Mante, D.O.; Peters, J.E. Biomass hydropyrolysis in a fluidized bed reactor. Energy Fuels 2016, 30(60), 4879-4887.

56. Fernando, I.; Resende, P. Recent advances on fast hydropyrolysis of biomass. Catal. Today 2016, 269, 148-155.

57. Stefanidis, S.D.; Kalogianis, K.G.; Pilavachi, P.A.; Fougret, C.M.; Jordan, E.; Lappas, A.A. Catalyst hydrothermal deactivation and metal contamination during in situ catalytic pyrolysis of biomass. Catal. Sci. Technol., 2016, 6, 2807-2819.

58. Paasikallio, V.; Lindfors, C.; Kuoppala, E. et al. Product quality and catalyst deactivation in a four day catalytic fast pyrolysis production run. Green Chemistry 2014, 16(7), 3549. 
59. Yildiz, G.; Ronsse, F.; Venderbosch, R.; Duren, R.V.; Kersten, S.R.A.; Prins, W. Effect of biomass ash in catalytic fast pyrolysis of pine wood. Appl. Catal. B: Environ. 2015, 168169:203-211.

60. Yathavan, B.K.; Agblevor, F.A. Catalytic pyrolysis of pinyon-juniper using red mud and HZSM-5. Energy Fuels 2013, 27, 6858-6865.

61. Gungor, A.; Onenc, S.; Ucar, S.; Yanik, J. Comparison between one step and two-step catalytic pyrolysis of pine back. J. Appl. Anal. Pyrol, 2012, 97, 39-48.

62. Kidane, Y.A. Catalytic fast pyrolysis of whole field pennycress biomass, MS Thesis, Utah State University, 2015.

63. Veses, A.; Aznar, M.; Lopez, J.M.; Callen, M.S.; Murillo, R.; Garcia, T. Production of upgraded bio-oils by biomass catalytic pyrolysis in an auger reactor using low cost materials. Fuel 2015, 141, 17-22.

64. Wang SQ, Xu MI, Wang F, Li ZH, 2016. Preparation of bio-oil by catalytic pyrolysis of corn stalks using red mud. Int. J. Agric. Biol. Eng. 2016, 9(5), 177-183.

65. Wang, S.; Li, Z.; Xai, X., Yi, W.; Fu, F. Catalytic pyrolysis of lignin in a cascade dual catalyst system of modified red mud and HZSM-5 for aromatic hydrocarbon production. Biores. Technol., 2019, 278, 66-72.

66. Gupta, J.; Papadikis, K.; Kozhevnikov, I.V.; Konysheva, E.Y. Exploring the potential of red mud and beechwood co-processing for the upgrading of fast pyrolysis vapors. J. Anal. Appl. Pyrol. 2017, 128, 35-43.

67. Lim, X.; Sanna, A.; Anresen, J.M. Influence of red mud impregnation on the pyrolysis of biomass-EFB. Fuel 2014, 118, 259-265.

68. Joilet, V.; Gissane, C.; Schlaf, M. Optimization of the neutralization of red mud by pyrolysis bio-oil using a design of experiments approach. Energy Environ. Sci, 2014, 7, 1125.

69. Kar, Y. Catalytic cracking of pyrolytic oil using bentonite clay for green liquid hydrocarbon fuels production. Biomass Bioenergy 2018, 119, 473-479.

70. Dou, G.; Goldfarb, J.L. 2017. In situ upgrading of pyrolysis biofuels by bentonite clay with simultaneous production of heterogeneous adsorbents for water treatment. Fuel 2017, 195, 273-283.

71. Mante, O.D.; Dayton, D.C.; Carpenter, J.R.; Wang, K.; Peters, J.E. Pilot-scale catalytic fast pyrolysis of loblolly pine over $\mathrm{y}-\mathrm{Al}_{2} \mathrm{O}_{3}$ catalyst. Fuel 2018, 214, 569-579.

72. Imran, A.; Bramer, E.A.; Seshan, K.; Brem, G. 2014. High quality bio-oil from catalytic flash pyrolysis of lignocellulosic biomass over alumina-supported sodium carbonate. Fuel Process. Technol. 2014, 127, 72-79.

73. Agblevor, F.A.; Elliott, D.C.; Santosa, D.M.; Olarte, M.V.; Barton, D.M.; Swita, M.; Beis, S., Christian, K., Sargent, B. Red mud catalytic pyrolysis of pinyon juniper and single stage hydrotreating of oil. Energy Fuel 2016, 30, 7947-7958.

74. Jahromi, H.; Agblevor, F.A. Upgrading of pinyon-juniper catalytic pyrolysis oil via hydrodeoxygenation. Energy 2017, 141, 2186-2195. 
75. Agblevor, F.A.; Scahill, J.; Johnson, D.K. Pyrolysis Char Catalyzed Destabilization of Biocrude Oils, In Innovative Advances in Forest Products Industries; B.N. Brogdon, B.N.; Hart, P.W.; J.C. Ransdell, J.C.; Scheller, B.L., Eds. AIChE Symposium Series 319; American Institute of Chemical Engineers: New York, 1998; Vol. 94, pp 146-150.

76. Hwang, H.; Oh, S.; Cho, T.S.; Choi, I-G.; Choi, J.W. Fast pyrolysis of potassium impregnated poplar wood and characterization of its influence on the formation as well as properties of pyrolytic products. Biores. Technol. 2013, 150, 359-366.

77. Eom, I-Y.; Kim, J-Y.; Kim, T-S, Lee, S-M.; Choi, D.; Choi, I-G. Effect of essential inorganic metals on primary thermal degradation of lignocellulosic biomass. Biores. Technol. 2012, 104, 687-694.

78. Yang, H.; Yan, R.; Chen, H.; Zheng, C.; Lee, D.H.; Liang, D.T. Influence of mineral matter on pyrolysis of palm oil wastes. Combustion Flame 2006, 146, 605-611.

79. Williams, P.T.; Horn, P.A. The role of metal salts in the pyrolysis of biomass. Renew. Energy 1994, (1), 1-13.

80. Richards, G.N.; Zheng, G. Influence of metal ions and of salts on products from pyrolysis of wood: applications to thermochemical processing of newsprint. J. Anal. Appl. Pyrol. 1991, 21, 133-146.

81. Shimada, N.; Kawamoto, H.; Saka, S. Different action of alkali/alkaline earth metal chlorides on cellulose pyrolysis. J. Anal. Appl. Pyrol. 2008, 81, 80-87.

82. Patwardhan, P.R.; Satrio, J.A.; Brown, R.C.; Shanks, B.H. Influence of inorganic salts on the primary pyrolysis products of cellulose. Biores. Technol. 2010, 101, 4646-4655.

83. Szabo, P.; Varhegyi, G.; Till, F.; Faix, O. Thermogravimetric/mass spectrometric characterization of two energy crops, Arundo donax and Miscanthus sinesis. J. Anal. Appl. Pyrol. 1996, 36, 179-190.

84. Carvalho, W.S.; Cunha, I.F.; Pereira, M.S.; Ataíde, C.H. Thermal decomposition profile and product selectivity of analytical pyrolysis of sweet sorghum bagasse: Effect of addition of inorganic salts. Ind. Crops Prod. 2015, 74, 372-380.

85. Di Blasi, C.; Branca, C.; Galgano, A.; Zenone, F. Modifications in the thermicity of the pyrolysis reactions of $\mathrm{ZnCl}_{2}$-loaded wood. Ind. Eng. Chem. Res. 2015 , 54, 12741-127419.

86. Branca, C.; Di Blasi, C.; Galgano, A. Pyrolysis of corncobs catalyzed by zinc chloride for furfural production. Ind. Eng. Chem. Res. 2010, 49, 9743-52.

87. Lu, Q.A.; Dong, C.Q.; Zhang, X.M.; Tian, H.Y.; Yang,Y.P.; Zhu, X.F. Selective fast pyrolysis of biomass impregnated with $\mathrm{ZnCl}_{2}$ to produce furfural: analytical PyGC/MS study. J Anal Appl. Pyrol. 2011, 90, 204-12.

88. Agblevor, F.A.; Abdellaoui, H.; Hallouani, K.; Beis, S.H. Pyrolytic Conversion of Olive Mill Wastewater Sludge to Biofuels Using Red Mud as Catalyst. Internal. J. Energy Power Eng. 2017, 6 (6), 108-120. DOI: 10.11648/j.ijepe.20170606.14.

89. Mourant, D.; Wang, Z.; He, M.; Wang, X.S.; Garcia-Perez, M.; Ling, K.; Li, C.Z. Mallee wood fast pyrolysis: effects of alkali and alkaline earth metallic species on the yield and composition of biooil. Fuel 2011, 90, 2915-2922. 
90. Baxter, L.L.; Miles, T.R.; Miles Jr, T.R.; Jenkins, B.M.; Milne, T.; Dayton, D.; Bryers, R.W.; Oden, L.L. The behavior of inorganic material in biomass-fired power boilers: field and laboratory experiences, Fuel Process. Technol. 1998, 54 (1-3), 47-78.

91. Olsson, J.G.; Jagli, U.; Pettersson, J.B.C. Alkali metal emission during pyrolysis of biomass, Energy Fuels 1997, 11, 779-74.

92. Dayton, D.C.; French, R.J.; Milne, T.A. Direct Observation of Alkali Vapor Release during Biomass Combustion and Gasification. 1. Application of Molecular Beam/Mass Spectrometry to Switchgrass Combustion, Energy Fuels 1995, 9, 855-865. 